Original paper

\title{
Oxide minerals in the granitic cupola of the Jálama Batholith, Salamanca, Spain. Part I: accessory Sn, Nb, Ta and Ti minerals in leucogranites, aplites and pegmatites
}

\author{
Teresa LLORENS*, María Candelas MORO \\ Department of Geology, University of Salamanca, Plaza de los Caidos s/n, 37006 Salamanca, Spain; tllg@usal.es \\ * Corresponding author
}

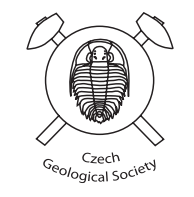

$\mathrm{Sn}-\mathrm{Nb}-\mathrm{Ta}-\mathrm{Ti}$ oxides occur as accessory minerals in the granitic facies of the External Unit in the Jálama Batholith (Salamanca, Spain) and in the related LCT pegmatite dikes of the rare-element class. Moreover, abundant cassiterite and columbite-group minerals crystallized in the Cruz del Rayo peribatholithic pegmatite dikes, cutting the pre-Ordovician low-grade metasedimentary rocks of the surrounding Schist-Graywacke Complex.

Cassiterite, rutile, ilmenite and tantalite-(Fe) occur disseminated in the border facies of the External Unit, especially throughout the tourmaline-bearing leucogranite and the apical aplites. Additionally, cassiterite, rutile and Ta-rich rutile developed locally in the intragranitic pegmatite dikes.

Two types of peribatholithic pegmatites can be distinguished at Cruz del Rayo: (i) granite-like pegmatites, with columbite-(Fe) I and II and cassiterite, in which the influence of metasomatic fluids led to formation of the late albite unit and crystallization of tantalite-(Fe), and (ii) greisen-like bodies, which contain high amounts of columbite-(Fe), columbite(Mn), tantalite-(Mn) I and II as well as cassiterite.

The primary oxide assemblage in both types of the peribatholithic pegmatite dikes would have crystallized as a result of magmatic differentiation of the residual melts coming from the Jálama granitic cupola. However, crystallization of the secondary assemblage, richer in $\mathrm{Fe}$ and $\mathrm{Ta}$, is interpreted mainly as a consequence of interaction with external fluids coming from the metamorphic host rocks, more or less mixed with meteoric fluids, although partial dissolution and re-precipitation could have played an important role, as well.

Keywords: Jálama Batholith, pegmatite dikes, cassiterite, columbite-group minerals Received: 15 December 2011; accepted: 30 March 2012; handling editor: M. Novák

\section{Introduction}

Rare-metal granitic cupolas are generally strongly enriched in $\mathrm{F}$ and show variable $\mathrm{Sn}, \mathrm{W}, \mathrm{Nb}, \mathrm{Ta}, \mathrm{Rb}$, $\mathrm{Cs}, \mathrm{Be}$ and Li contents. Thus, they are mainly associated with $\mathrm{Sn}-\mathrm{Nb}-\mathrm{Ta}-\mathrm{Li}$ ores, which were deposited directly through magmatic crystallization processes or as a consequence of the late-hydrothermal alteration of these granitic bodies. In Europe, examples of such deposits are scattered throughout the Variscan Belt and they are spatially associated with peraluminous syn- to post-tectonic granitic cupolas, which frequently have high phosphorus contents. Li-rich muscovite or lepidolite, columbite-group minerals, and pyrochloregroup minerals are common in these deposits (Černý et al. 2005). Examples in the French Massif Central include the $\mathrm{Ta}-\mathrm{Sn}-\mathrm{Li}$ mineralization of the Beauvoir granite (Cuney et al. 1992; Raimbault et al. 1995), the columbite-tantalite minerals of the complex lepidolitesubtype pegmatites of Chèdeville (Raimbault 1998), as well as the cassiterite and wolframite-group minerals of the Vienne granite (Cuney et al. 2002; Bouchot et al. 2005). The rare-metal deposits linked to the LCT pegmatites occur also in the Bohemian Massif, Czech Republic (Johan and Johan 1994; Černý et al. 2007; Breiter et al. 2007) and the tin and tungsten deposits are known from the Cornwall Massif, south-eastern England (Charoy 1986; Willis-Richards and Jackson 1989). In the Iberian Massif, the pegmatite fields of Lalín-Forcarei (Fuertes-Fuentes and Martín-Izard 1998) and Fregeneda-Almendra (Roda-Robles 1993; Roda-Robles et al. 2007; Vieira et al. 2011) are some of the best-known rare-metal deposits associated with leucogranites in northern and western Spain.

The late-Variscan granitic cupola of the Jálama Batholith (Ramírez 1996; Ramírez and Grundvig 2000), which is located in the central-western part of the Spanish Iberian Massif, is another good example of these rare-metal deposits. It belongs to the Navasfrías $\mathrm{Sn}-\mathrm{W}$ district (geographic coordinates 40.265708, -6.79616), which was mined irregularly during the second half of the last century to obtain cassiterite and wolframite-group minerals from aplites, pegmatites and a group of hydrothermal quartz veins (Fig. 1). Already Fernández-Leyva 
(2007) and Ruiz et al. (2008) established the potential geochemical indicators of the rare-metal mineralization. Recently, Llorens and Moro (2010a) have reported the existence of a rare $\mathrm{Nb}$ - Ta deposit hosted by the Li-rich LCT pegmatites of La Canalita, which are also related to another granitic cupola in the Navasfrías district; namely, the Cadalso-Casillas de Flores Batholith.

This contribution reports the occurrence of the $\mathrm{Nb}$, $\mathrm{Ta}, \mathrm{Sn}$ and Ti oxide minerals disseminated in the leucogranite and the aplites of the Jálama Batholith, as well as in the intra- and peribatholithic pegmatite dikes. Here we: 1) report results of petrographic and mineralogical study, textural relations, and chemical data for the $\mathrm{Nb}$-, Ta-, Sn-, Ti-bearing minerals, paying special attention to their zoning patterns, 2) discuss the mechanism of chemical substitution in individual ore minerals, 3) assess the chemical evolution of these oxides related both to the magmatic stage and the batholith's hydrothermal alteration, and 4) discuss the factors controlling the likely formation of these oxides.

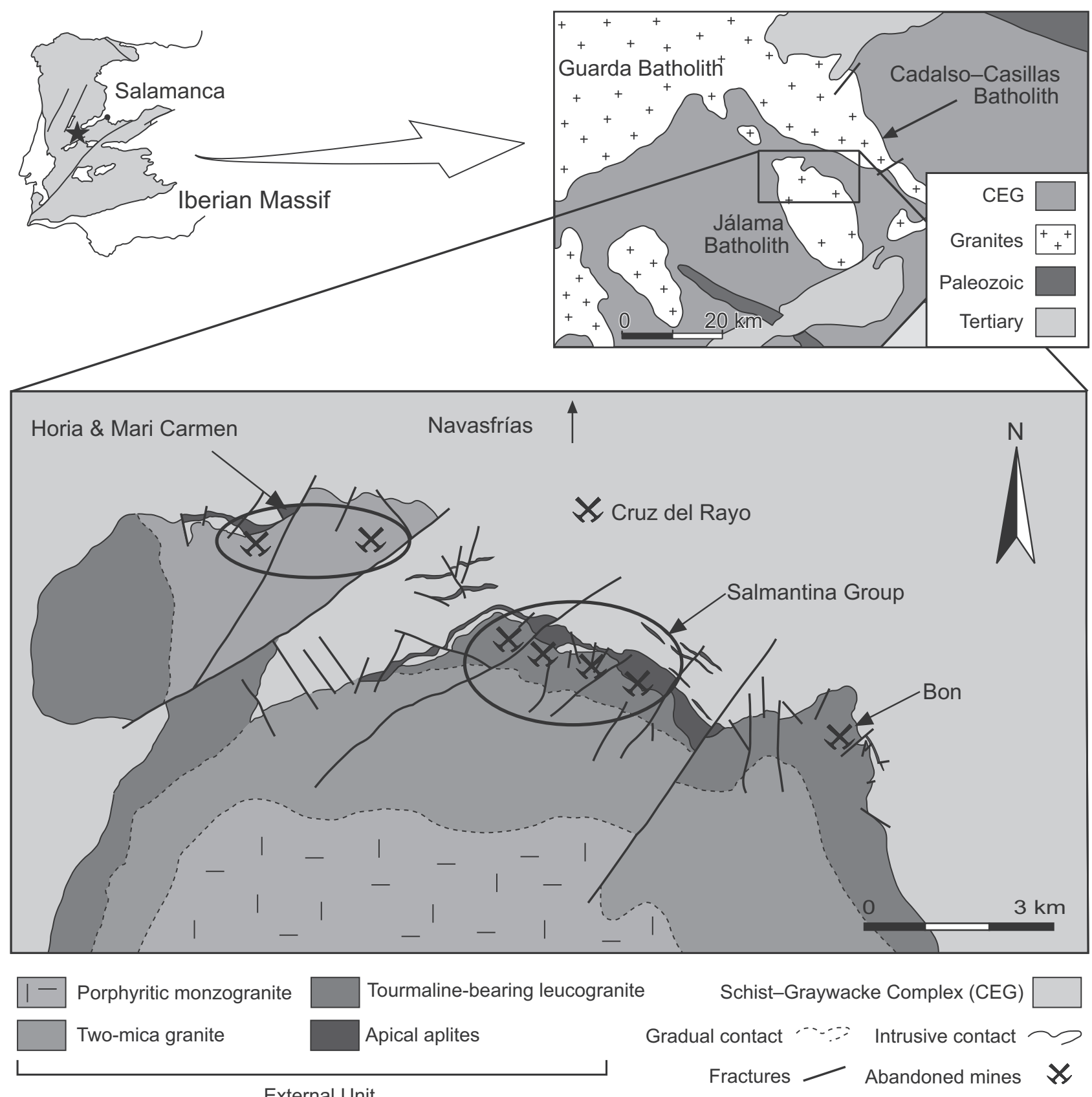

External Unit

Fig. 1 Simplified geological map of the Jálama Batholith and the old mining works in the central part of the Spanish Variscan Massif. Based on Ramírez (1996). 


\section{Geological setting}

The Jálama Batholith is an elliptical allochthonous and discordant body striking NNW-SSE. It intruded the Schist-Graywacke Complex (CEG) of the central-western Iberian Peninsula (Martínez Catalán et al. 2004) after the main Variscan deformation phase ( $300 \mathrm{Ma}$, Ramírez 1996). In the study area, the CEG includes large outcrops of pre-Ordovician graywacke-pelite metasediments affected by low-grade regional metamorphism (Rodríguez Alonso 1985; Díez Balda et al. 1990), overprinted by the contact-metamorphic aureole of the Jálama Batholith.

The $\mathrm{Sn}, \mathrm{Nb}, \mathrm{Ta}$ and Ti oxide minerals studied in this contribution occur in the northern part of the Jálama Batholith: the so-called External Unit (EU) of Ramírez (1996) and Ramírez and Grundvig (2000). According to these authors, the EU represents a magmatic differentiation series constituted, from south to north, by coarsegrained porphyritic monzogranite, two-mica equigranular granite, tourmaline-bearing leucogranite, and a group of aplitic and pegmatitic dikes cutting the metamorphic aureole (Fig. 1). The hydrothermal alteration of the EU caused a progressive increase in modal proportions of muscovite, albite and tourmaline at expense of biotite and K-feldspar. Sulphides (e.g. arsenopyrite, chalcopyrite, pyrite and loellingite), together with phosphates (e.g. apatite, montebrasite, rockbridgeite and childrenite-eosphorite), are the most common accessory minerals (Llorens and Moro 2012), being especially concentrated in the most fractionated and marginal facies of the batholith.

All the granitic facies of the Jálama Batholith are strongly peraluminous, with ASI ranging from 1.15 and 1.44 [ASI being the $\mathrm{Al}_{2} \mathrm{O}_{3} /\left(\mathrm{CaO}+\mathrm{Na}_{2} \mathrm{O}+\mathrm{K}_{2} \mathrm{O}\right)$ molar ratio]. Moreover they show high, with differentiation further increasing contents of $\mathrm{SiO}_{2}$ (68.73 to 75.50 wt. \%) and $\mathrm{P}_{2} \mathrm{O}_{5}(0.27$ to $0.51 \%)$ as well as trace elements such as $\mathrm{Li}, \mathrm{Rb}, \mathrm{Cs}, \mathrm{Be}, \mathrm{Sn}$ and $\mathrm{Tl}$ (Ramírez and Grundvig 2000). For example, the amounts of Sn vary from $9 \mathrm{ppm}$ in the porphyritic monzogranite to $66 \mathrm{ppm}$ in the leucogranite, and $55 \mathrm{ppm}$ in the border aplites. However, the $\mathrm{Nb}$ and $\mathrm{Ta}$ contents remained more or less constant during the differentiation (at c. $30 \mathrm{ppm}$ and 12 ppm respectively), reaching $46 \mathrm{ppm} \mathrm{Nb}$ and $58 \mathrm{ppm} \mathrm{Ta}$ in the tourmaline-bearing leucogranite and border aplites (Ramírez and Grundvig 2000; Fernández-Leyva 2007; Ruiz et al. 2008).

A suite of pegmatite bodies is hosted by the different facies of the EU of the Jálama Batholith. The dikes cutting the two-mica equigranular granite (Horia and Mari Carmen, Fig. 1) are homogeneous or poorly zoned, striking $\mathrm{N} 170-180^{\circ} \mathrm{E}$, and mainly composed of K-feldspar, albite, muscovite and quartz (Fig. 2a). In contrast, the pegmatites hosted by the tourmaline-bearing leucogranite and the apical aplites are $10-50 \mathrm{~cm}$ thick and up to $100 \mathrm{~m}$ long, striking mainly between $\mathrm{N} 120^{\circ} \mathrm{E}$ and $\mathrm{N} 180^{\circ} \mathrm{E}$ (the Salmantina Group and Bon, Fig. 1). They form tabular, lenticular bodies or ellipsoidal pods consisting of albite, microcline, quartz and muscovite and showing a poor zoning pattern (Fig. 2b). Moreover, they contain variable but accessory amounts of $\mathrm{Mn}-\mathrm{Fe}-\mathrm{Ca}$ phosphates (Llorens and Moro 2007, 2008, 2012) and, locally, also tourmaline, biotite, zircon and $\mathrm{Fe}$ - with $\mathrm{Cu}$-rich sulphides.

The largest pegmatite bodies, and indeed the only ones that have been mined for Sn, correspond to the LCT pegmatites of the rare-element class (Černý and Ercit 2005). They occur at Cruz del Rayo, where they intruded the metamorphic rocks of the CEG (Fig. 1). These include three main lenticular dikes striking $\mathrm{N} 170^{\circ} \mathrm{E}$, with subvertical dip and secondary ramifications. They range from $20 \mathrm{~cm}$ to $1 \mathrm{~m}$ in width and have a maximum length of $300 \mathrm{~m}$. The average estimated contents reach $600 \mathrm{ppm}$ $\mathrm{Sn}$ and $22 \mathrm{ppm} \mathrm{Nb}$ and $\mathrm{Ta}$; hence the mining works included mainly shallow excavations of the individual dikes down to $6 \mathrm{~m}$. However, currently the mining works are not active and they have not been preserved for mapping purposes. Pegmatite dikes of granite-like composition and greisen-like bodies were identified (for a detailed description, see Llorens and Moro 2012), both showing internal zoning (Fig. 2c). Pegmatite bodies of granite-like composition mainly consist of albite, sometimes with the "cleavelandite" habit, K-feldspar, quartz and muscovite. Alluaudite, mitridatite, rockbridgeite and apatite appear as accessory minerals in the outermost zones of the bodies. Later metasomatic processes resulted in the development of a unit mainly made up by saccharoidal albite, forming fracture-fillings and building groundmass, especially in the intermediate zones. Finally, greisenization gave rise to the crystallization of the greisen-like pegmatite dikes, which are almost exclusively composed of quartz and muscovite and host the main $\mathrm{Sn}, \mathrm{Nb}$ and Ta oxide minerals (Fig. 2d). Tourmaline and apatite are accessory minerals in the outermost zones of the dikes, whereas the quantities of amblygonite-montebrasite and beryl increase progressively towards intermediate zones.

\section{Analytical techniques}

All samples were collected in situ from several zones of the Jálama Batholith (Fig. 1). Only the Cruz del Rayo pegmatite samples came from the surrounding dumps owing to the difficulty in accessing the outcrops and previous restoration works. Of the 66 samples collected (33 belonged to granites and aplites, 20 to intragranitic pegmatite dikes, and 13 to the Cruz del Rayo peribatholithic pegmatite dikes), 23 were selected for petrographic and chemical analyses. Where internal zoning patterns were present in the pegmatite bodies, samples were taken from 

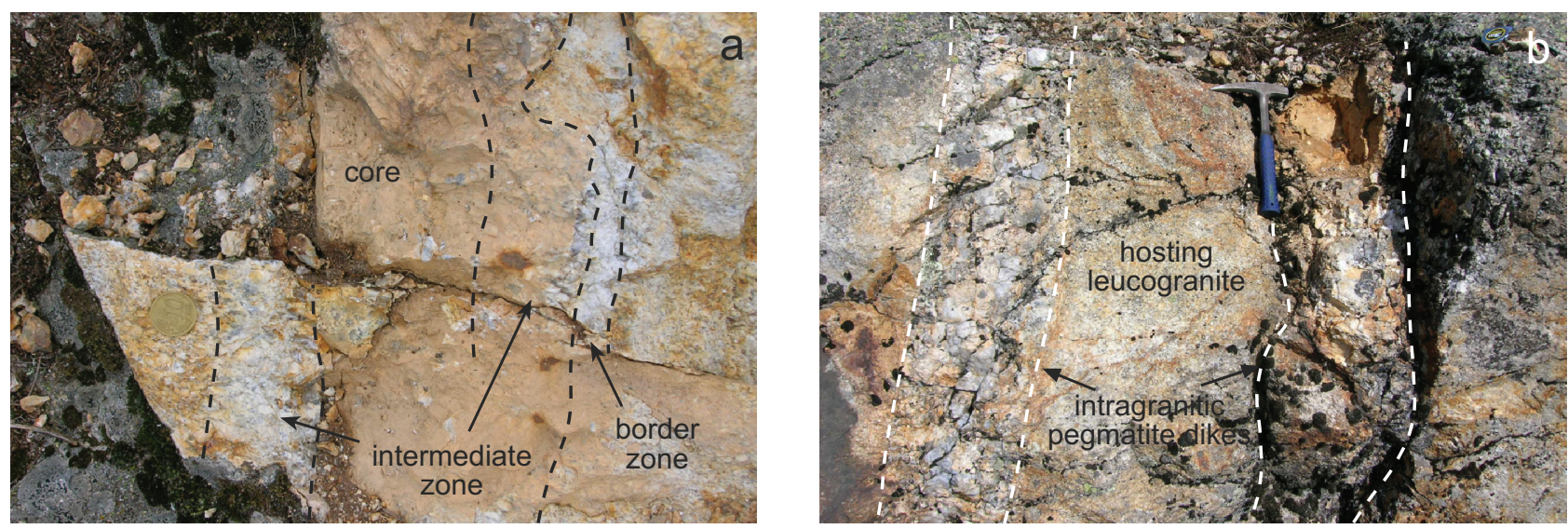

Granite-like pegmatites

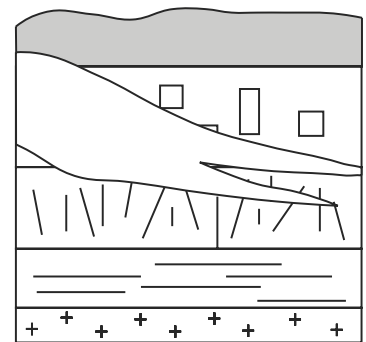

$\overrightarrow{+}_{+}^{+}+\Downarrow \Downarrow$ Border zone

$\square . \bigvee$ Wall zone

$\backslash \mathrm{I} / \mathrm{I} \backslash$ Outer intermediate zone

(I)

$\square \square$ Inner intermediate zone

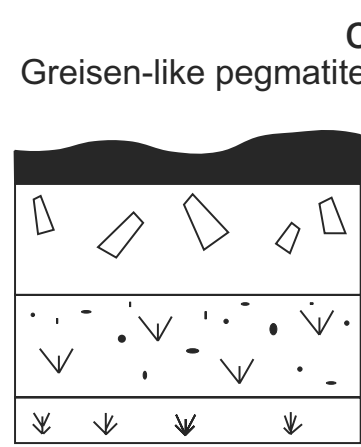

Intermediate zone $\Delta \square$

Core margin

Core

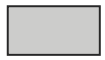

$1 \mathrm{~cm}$

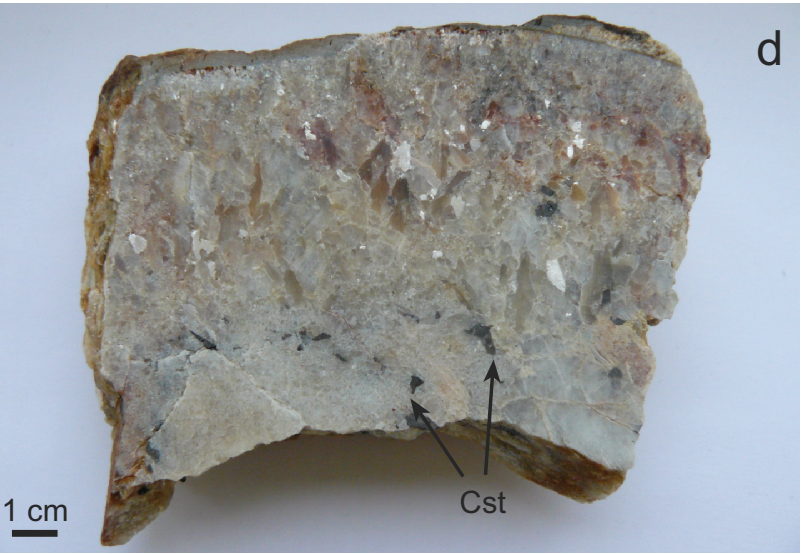

Fig. 2a - Poorly zoned pegmatite dikes striking $\mathrm{N} 180^{\circ} \mathrm{E}$ and hosted by the two-mica equigranular granite. $\mathbf{b}-\mathrm{Pegmatite}$ dikes striking $\mathrm{N} 180^{\circ} \mathrm{E}$ with a subvertical dip, cutting the tourmaline-bearing leucogranite, $\mathbf{c}$ - Schematic sections of the Cruz del Rayo peribatholithic pegmatites, showing the zoning pattern of both types of pegmatite dikes: the granite- and greisen-like ones. d - Sample of a greisen-like pegmatite dike, showing a contact zone with the metamorphic host rock in its upper part and disseminated crystals of cassiterite towards the bottom.

each zone, although in some cases the thinness of several dikes rendered such identification impossible.

The millimetre size of most of the $\mathrm{Sn}, \mathrm{Nb}, \mathrm{Ta}$ and $\mathrm{Ti}$ oxide minerals hindered their separation, such that the use of X-ray diffraction was not possible. Thus, their identification was based on combined optical and electron microscopy, as well as chemical composition, obtained by electron-microprobe analysis (EMPA). We employed a Cameca SX-100 electron microprobe at the ScientificTechnical Services of the University of Oviedo, which was operated with an accelerating potential of $20 \mathrm{kV}$ and a sample current of $20 \mathrm{nA}$. The counting time was $20 \mathrm{~s}$ for $\mathrm{Zr}, \mathrm{W}, \mathrm{Fe}, \mathrm{Ta}, \mathrm{Bi}, \mathrm{U}$ and $\mathrm{Al}$, and $10 \mathrm{~s}$ for the rest of elements. The detection limits ranged between 0.01 and 0.04 , and standard deviations between \pm 0.02 to \pm 0.10 for main elements and up to 0.11 and between \pm 0.12 to \pm 0.34 , respectively, for trace elements. The following standards were used: metals for Ti, Sn, W, Zr and $\mathrm{Bi}$; vanadinite for $\mathrm{V}$; magnetite for $\mathrm{Fe}$; $\mathrm{MnTiO}_{3}$ for $\mathrm{Mn} ; \mathrm{Ta}_{2} \mathrm{O}_{5}$ for $\mathrm{Ta} ; \mathrm{Nb}_{2} \mathrm{O}_{5}$ for $\mathrm{Nb}$; andradite for $\mathrm{Ca}$, and corundum for Al. Back-scattered electron (BSE) images and semi-quantitative analyses were obtained using SEM at the Scientific-Technical Services of the University of Oviedo and at the University of Salamanca (ZEISS DSM 940) in order to determine compositional variations and the possible zoning of the oxide minerals.

\section{Mineralogy and chemistry of the Sn- $\mathrm{Nb}-\mathrm{Ta}-\mathrm{Ti}$ assemblage}

The $\mathrm{Sn}, \mathrm{Nb}$, Ta, and Ti oxides studied in this work occur as accessory minerals disseminated throughout the different granitic facies that constitute the EU at the northern 
part of the Jálama Batholith. Three mineral assemblages can be recognized: 1) cassiterite, rutile, ilmenite and tantalite-(Fe), disseminated in the border facies of the EU and, in particular, the tourmaline-bearing leucogranite and apical aplites, 2) cassiterite, rutile and Ta-rich rutile in the intragranitic pegmatite dikes, and 3) cassiterite and columbite-group minerals in the Cruz del Rayo peribatholithic pegmatite dikes hosted by the contact metamorphic aureole.

\subsection{Tourmaline-bearing leucogranite and aplites}

Cassiterite is the main accessory mineral in the marginal granitic facies in the EU of the Jálama Batholith. It occurs as millimetre-sized anhedral crystals, normally associated with muscovite. Cassiterite usually includes earlier minerals, suggesting crystallization from late hydrothermal fluids. Rutile and ilmenite crystallized as mil- limetre- to micrometre-sized crystals, commonly showing fibrous textures, enclosed in biotite and muscovite or in chlorite, derived from their alteration (Fig. 3a-b). Finally, tantalite- $(\mathrm{Fe})$ with a mean chemical formula of $\left(\mathrm{Fe}_{0.76} \mathrm{Mn}_{0.19}\right)_{\Sigma 0.96}\left(\mathrm{Ta}_{1.09} \mathrm{Nb}_{0.8} \mathrm{Ti}_{0.1} \mathrm{Sn}_{0.04}\right)_{\Sigma 2} \mathrm{O}_{6}$ is found locally disseminated in the tourmaline-bearing leucogranite.

\subsection{Intragranitic pegmatites}

Cassiterite is scarce in the pegmatite dikes hosted by the tourmaline-bearing leucogranite and the apical aplites, whereas it is lacking completely in the dikes hosted by the two-mica equigranular granite. Cassiterite occurs as millimetre-sized anhedral to subhedral crystals that are usually associated with muscovite and quartz (Fig. 3c). Its composition is rather homogeneous (Tab. 1) with $\mathrm{Sn}$ (0.976-0.987 apfu) substituted solely by small amounts of Ti and Fe (up to 0.007 apfu each). Only a few cassiterite crystals show a limited degree of substitution by Ta
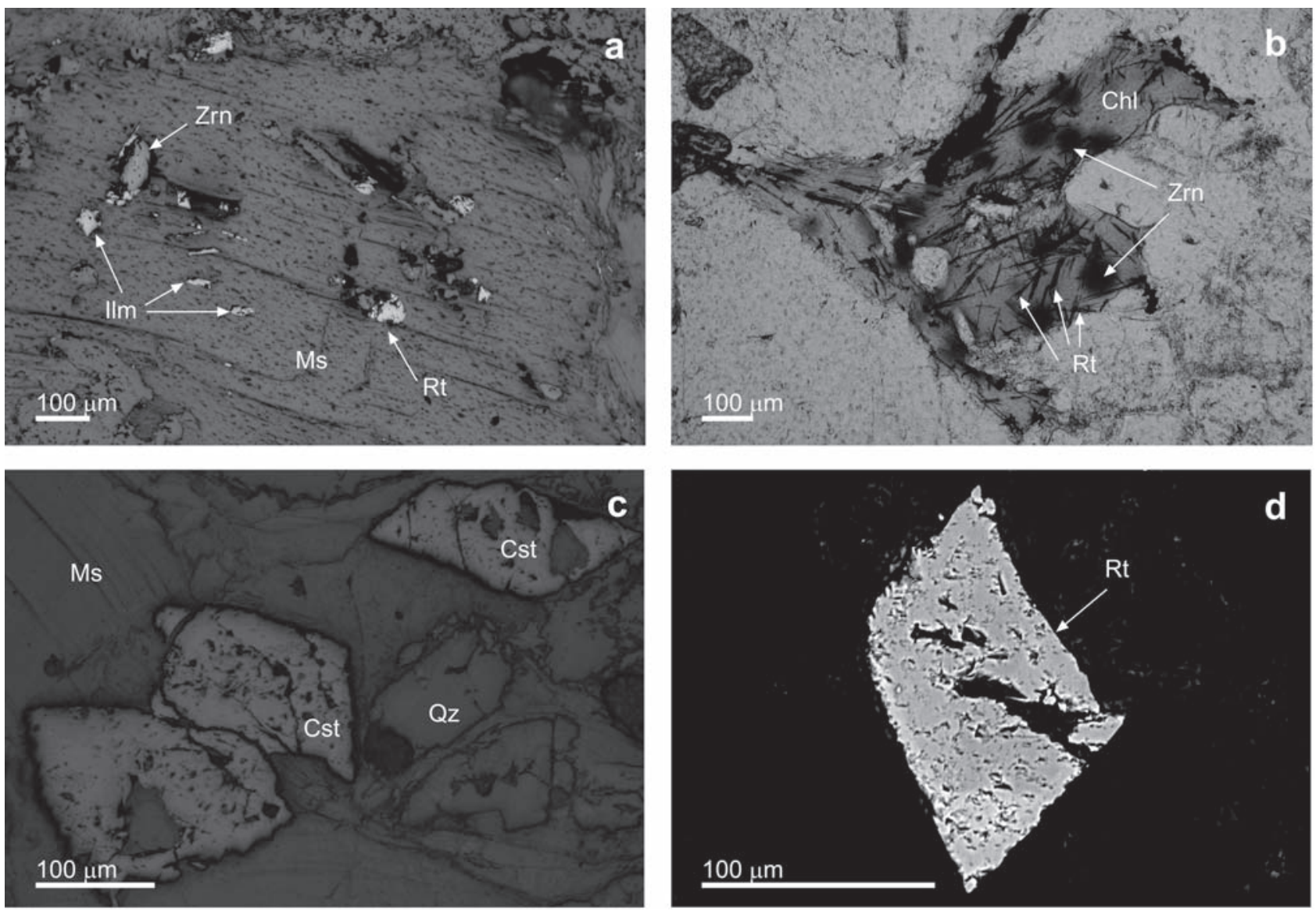

Fig. 3 Photomicrographs and BSE images of several Sn and Ti accessory oxides disseminated in the tourmaline-bearing leucogranite and apical aplites (a-b) and in the intragranitic pegmatite dikes $(\mathbf{c}-\mathbf{d})$ : $\mathbf{a}$ - rutile and ilmenite crystallized in the foliation planes of muscovite (plain reflected light); $\mathbf{b}$ - acicular crystals of rutile in chlorite formed by biotite alteration. Zircon crystals surrounded by pleochroic halos (dark circular patches) are also observed (plain transmitted light); $\mathbf{c}-$ crystals of cassiterite in association with muscovite (plain reflected light); $\mathbf{d}-$ BSE image of a poorly zoned euhedral crystal of rutile, showing higher $\mathrm{Nb}$ and Ta contents towards its rims. Rt: rutile, Ilm: ilmenite, Ms: muscovite, Zrn: zircon, Chl: chlorite, Cst: cassiterite, Qz: quartz. 
Tab. 1 Representative compositions of cassiterite and rutile in the intra- and peribatholithic pegmatite dikes (wt. \% and apfu)

\begin{tabular}{|c|c|c|c|c|c|c|c|c|c|c|}
\hline \multirow{3}{*}{$\begin{array}{l}\text { Pegmatite type } \\
\text { Mineral }\end{array}$} & \multicolumn{5}{|c|}{ Intragranitic } & \multicolumn{5}{|c|}{ Peribatholithic } \\
\hline & \multicolumn{5}{|c|}{ Hosted by leucogranite and aplites } & \multirow{2}{*}{$\begin{array}{c}\text { Granitic } \\
\text { Cst }\end{array}$} & \multirow{2}{*}{$\begin{array}{c}\text { Greisen } \\
\text { Cst }\end{array}$} & \multicolumn{3}{|c|}{ Late Unit } \\
\hline & Cst & Cst & Rt & Rt & Ta-Rt & & & Cst & Cst & Cst \\
\hline Analyses & 0.1 & 3.4 & 1.1 & 1.2 & 0.2 & 1.4 & 3.8 & 7.5 & 1.1 & 1.3 \\
\hline $\mathrm{WO}_{3}$ & b.d.l. & b.d.1. & 0.36 & b.d.1. & 0.00 & 0.00 & 0.00 & 0.00 & - & - \\
\hline $\mathrm{Nb}_{2} \mathrm{O}_{5}$ & 0.14 & 0.39 & 4.38 & 3.72 & 5.19 & 0.33 & 0.16 & 2.26 & 1.02 & 0.46 \\
\hline $\mathrm{Ta}_{2} \mathrm{O}_{5}$ & 1.07 & b.d.1. & 0.86 & 2.89 & 42.32 & 3.06 & 0.13 & 5.39 & 2.95 & 1.09 \\
\hline $\mathrm{TiO}_{2}$ & 0.15 & 0.41 & 90.36 & 87.02 & 32.99 & 0.23 & 0.09 & 0.13 & 0.21 & 0.18 \\
\hline $\mathrm{ZrO}_{2}$ & 0.00 & 0.00 & 0.00 & 0.00 & 0.00 & 0.00 & 0.00 & 0.00 & 0.00 & 0.00 \\
\hline $\mathrm{SnO}_{2}$ & 98.48 & 97.94 & 1.50 & 0.41 & 5.31 & 95.74 & 99.10 & 89.20 & 94.45 & 97.94 \\
\hline $\mathrm{Al}_{2} \mathrm{O}_{3}$ & 0.00 & 0.09 & 0.06 & 1.72 & 0.12 & b.d.l. & 0.00 & 0.08 & 0.07 & 0.00 \\
\hline $\mathrm{V}_{2} \mathrm{O}_{3}$ & 0.00 & 0.00 & 0.40 & 0.34 & 0.21 & 0.00 & 0.04 & b.d.1. & - & - \\
\hline $\mathrm{CaO}$ & 0.53 & 0.55 & 0.02 & 0.06 & 0.05 & 0.51 & 0.53 & 0.49 & 0.00 & 0.00 \\
\hline $\mathrm{MnO}$ & b.d.l. & 0.00 & b.d.l. & 0.00 & 0.10 & 0.05 & 0.00 & 0.51 & b.d.l. & b.d.l. \\
\hline $\mathrm{FeO}$ & 0.25 & 0.21 & 2.28 & 2.80 & 9.30 & 0.64 & 0.13 & 0.92 & 0.52 & 0.22 \\
\hline Total & 100.67 & 99.74 & 100.25 & 99.03 & 95.59 & 100.57 & 100.185 & 99.00 & 99.23 & 99.91 \\
\hline $\mathrm{W}$ & 0.000 & 0.000 & 0.013 & 0.000 & 0.000 & 0.000 & 0.000 & 0.000 & 0.000 & 0.000 \\
\hline $\mathrm{Nb}$ & 0.001 & 0.004 & 0.027 & 0.024 & 0.048 & 0.003 & 0.002 & 0.023 & 0.010 & 0.005 \\
\hline $\mathrm{Ta}$ & 0.007 & 0.000 & 0.003 & 0.011 & 0.236 & 0.019 & 0.001 & 0.033 & 0.018 & 0.007 \\
\hline $\mathrm{Ti}$ & 0.002 & 0.007 & 0.932 & 0.925 & 0.510 & 0.004 & 0.001 & 0.002 & 0.004 & 0.003 \\
\hline $\mathrm{Zr}$ & 0.000 & 0.000 & 0.000 & 0.000 & 0.000 & 0.000 & 0.000 & 0.000 & 0.000 & 0.000 \\
\hline $\mathrm{Sn}$ & 0.979 & 0.978 & 0.009 & 0.003 & 0.049 & 0.956 & 0.987 & 0.906 & 0.955 & 0.980 \\
\hline Al & 0.000 & 0.002 & 0.001 & 0.029 & 0.003 & 0.000 & 0.000 & 0.002 & 0.002 & 0.000 \\
\hline V & 0.000 & 0.000 & 0.004 & 0.004 & 0.003 & 0.000 & 0.001 & 0.000 & 0.000 & 0.000 \\
\hline $\mathrm{Ca}$ & 0.013 & 0.0013 & 0.000 & 0.001 & 0.001 & 0.012 & 0.013 & 0.012 & 0.000 & 0.000 \\
\hline $\mathrm{Mn}$ & 0.000 & 0.000 & 0.000 & 0.000 & 0.002 & 0.001 & 0.000 & 0.010 & 0.000 & 0.000 \\
\hline $\mathrm{Fe}$ & 0.005 & 0.004 & 0.026 & 0.033 & 0.160 & 0.012 & 0.002 & 0.018 & 0.010 & 0.004 \\
\hline$\sum$ cat. & 1.007 & 1.009 & 1.006 & 1.034 & 1.012 & 1.007 & 1.007 & 1.007 & 0.999 & 1.000 \\
\hline $\mathrm{Mn} /(\mathrm{Mn}+\mathrm{Fe})$ & 0.039 & 0.000 & 0.006 & 0.000 & 0.011 & 0.077 & 0.000 & 0.360 & 0.035 & 0.097 \\
\hline $\mathrm{Ta} /(\mathrm{Ta}+\mathrm{Nb})$ & 0.818 & 0.109 & 0.106 & 0.319 & 0.831 & 0.849 & 0.333 & 0.589 & 0.635 & 0.587 \\
\hline
\end{tabular}

$\mathrm{N}^{\circ}$ of ions (in apfu) calculated on the basis of 2O. Cst: cassiterite, Rt: rutile, Ta-Rt: Ta-rich rutile, b.d.1.: below detection limit, - not analyzed.

and $\mathrm{Nb}$ (up to 1.07 wt. $\% \mathrm{Ta}_{2} \mathrm{O}_{5}$ and 0.39 wt. $\% \mathrm{Nb}_{2} \mathrm{O}_{5}$ ). Generally, $\mathrm{Nb}$ contents are invariably moderate, whereas Ta is either absent or its contents are comparably high.

Rutile crystallized less abundantly than cassiterite as micrometre- to millimetre-sized crystals or granular aggregates, disseminated in the pegmatite dikes or filling fractures together with muscovite (Fig. 3d). Chemically, Ti occupies most of the cationic site (up to $0.937 \mathrm{apfu}$ ), being substituted mainly by $\mathrm{Nb}$ and $\mathrm{Fe}$ (between 0.021 and 0.041 apfu each one), and, less commonly, by Ta and Sn (up to $0.024 a p f u$ in total). It was observed that rutile accommodates substantial amounts of $\mathrm{Al}$ in some intragranitic pegmatite dikes, reaching $1.72 \mathrm{wt}$ \% of $\mathrm{Al}_{2} \mathrm{O}_{3}$ (Tab. 1). The $\mathrm{Al}$ contents are even higher than those obtained for the rutile of the Podlesí granitic cupola in the Czech Republic (Breiter et al. 2007), which have been considered the most Al-enriched ever reported from any type of rock. The incorporation of $\mathrm{Al}$ into the rutile structure would be probably charge-balanced with oxygen vacancies by means of the $\mathrm{Al}_{2} \mathrm{Ti}_{-2} \mathrm{O}_{-1}$ substitution mechanism (Hata et al. 1996).
Finally, Ta-rich rutile occurs very locally in association with cassiterite, showing a mean formula of $\left(\mathrm{Ti}_{0.51} \mathrm{Ta}_{0.24} \mathrm{Nb}_{0.05} \mathrm{Sn}_{0.05} \mathrm{Fe}_{0.16}\right)_{\Sigma 1} \mathrm{O}_{2}$.

\subsection{The peribatholithic pegmatites of Cruz del Rayo}

In contrast to the intragranitic pegmatites, cassiterite is a very abundant oxide mineral in the peribatholithic pegmatite dikes of Cruz del Rayo, especially in the greisenlike ones. Moreover, a broad variety of columbite-group minerals occurs scattered throughout them (Llorens and Moro 2010b).

\subsubsection{Cassiterite}

Cassiterite appears in limited amounts in the granite-like pegmatite dikes, whereas in the late unit enriched in albite and the intermediate zones of the greisen-like dikes this mineral is abundant. Its optical and chemical proper- 

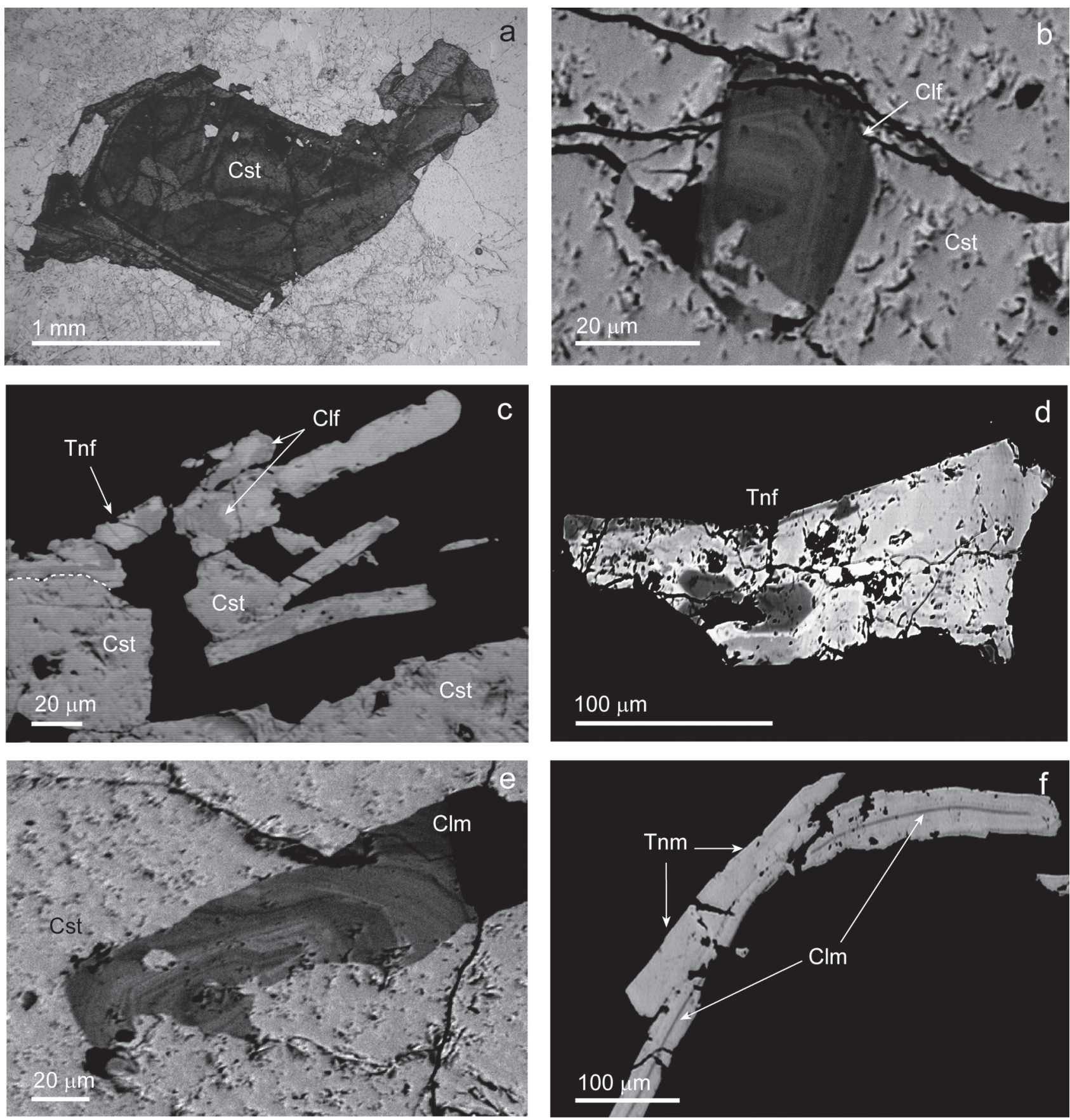

Fig. 4 Photomicrographs and BSE images of the main $\mathrm{Sn}, \mathrm{Nb}$ and Ta ore minerals hosted by the peribatholithic pegmatite dikes of Cruz del Rayo: $\mathbf{a}$ - zoned subhedral cassiterite crystal hosted by a greisen-like pegmatite dike (plain transmitted light); $\mathbf{b}$ - oscillatory-zoned crystal of columbite(Fe) I (Clf) hosted by cassiterite (Cst) in a granite-like pegmatite body; $\mathbf{c}$ - columbite-(Fe) II (Clf) and tantalite-(Fe) II (Tnf) included in cassiterite and quartz of a granite-like pegmatite dike; $\mathbf{d}$ - crystal of tantalite-(Fe), hosted by the late albite unit, shows a weak zoning owing to limited variations in the Ta contents; e - reverse zoning in columbite-(Mn) (Clm) I enclosed in cassiterite of a greisen-like pegmatite dike. The lighter zones are enriched in Ta, whereas the darker ones contain higher quantities of $\mathrm{Nb}$; $\mathbf{f}$ - columbite-(Mn) surrounded by tantalite-( $\mathrm{Mn})(\mathrm{Tnm})$ in an intermediate zone of a greisen-like pegmatite dike.

ties are similar in all kinds of rocks. Cassiterite mainly forms up to centimetre-sized anhedral to subhedral crystals that are especially common in the intermediate zones of the dikes. Microscopically, it exhibits a clearly zoned texture owing to alternating reddish and colourless growth zones, the latter enclosing numerous inclusions of columbite-group minerals (Fig. 4a). The reddish zones commonly contain higher amounts of $\mathrm{Fe}$ (up to 0.018 $a p f u$ ), $\mathrm{Nb}$ (up to $0.023 a p f u$ ) and Ta (up to 0.033 apfu) than the colourless ones. Moreover, $\mathrm{TiO}_{2}$ contents reach 
0.57 wt. $\%$ (Tab. 1), but any regular zoning in this element distribution throughout the cassiterite crystals could not be found.

\subsubsection{Columbite-group minerals}

The columbite-group minerals grew exclusively in the inner intermediate zones of the granite-like pegmatite dikes, whereas they crystallized in a disseminated manner throughout the different zones of the greisen-like dikes (Fig. 2c). Their chemical composition is highly variable, depending on that of their pegmatite dikes host.

Tab. 2 Representative compositions of columbite in the Cruz del Rayo peribatholithic pegmatites (wt. $\%$ and $a p f u$ )

\begin{tabular}{|c|c|c|c|c|c|c|c|}
\hline Peg. type & & Graniti & egmatite & & & Greisen & \\
\hline Mineral & Clf I & Clf I & Clf II & Clf II & Clf & $\mathrm{Clm}$ & $\mathrm{Clm}$ \\
\hline Analyses & 2.1 & 2.6 & 1.2 & 1.5 & 8.7 & 6.4 & 8.9 \\
\hline $\mathrm{WO}_{3}$ & 0.00 & 1.22 & 0.48 & 2.07 & 0.94 & 3.80 & 1.01 \\
\hline $\mathrm{Nb}_{2} \mathrm{O}_{5}$ & 42.68 & 50.87 & 31.25 & 33.71 & 57.92 & 45.02 & 55.95 \\
\hline $\mathrm{Ta}_{2} \mathrm{O}_{5}$ & 35.80 & 23.87 & 47.95 & 42.23 & 20.50 & 30.91 & 21.32 \\
\hline $\mathrm{TiO}_{2}$ & 3.48 & 4.72 & 2.07 & 1.98 & 1.67 & 2.14 & 0.84 \\
\hline $\mathrm{ZrO}_{2}$ & b.d.1. & 0.00 & 0.31 & 0.08 & 0.00 & 0.00 & 0.00 \\
\hline $\mathrm{SnO}_{2}$ & 2.15 & 1.45 & 1.02 & 0.69 & 0.45 & 0.48 & 2.18 \\
\hline $\mathrm{Al}_{2} \mathrm{O}_{3}$ & 0.07 & 0.00 & 0.02 & 0.25 & 0.05 & b.d.1. & b.d.l. \\
\hline $\mathrm{V}_{2} \mathrm{O}_{3}$ & b.d.l. & 0.03 & b.d.l. & 0.00 & 0.00 & 0.00 & b.d.l. \\
\hline $\mathrm{CaO}$ & 0.02 & 0.02 & 0.04 & 0.08 & 0.02 & 0.03 & 0.08 \\
\hline $\mathrm{MnO}$ & 1.15 & 6.38 & 7.19 & 7.16 & 8.26 & 11.29 & 14.37 \\
\hline $\mathrm{FeO}$ & 15.34 & 11.34 & 8.76 & 10.84 & 10.54 & 6.49 & 4.25 \\
\hline Total & 100.74 & 99.90 & 99.11 & 99.09 & 100.34 & 100.17 & 100.02 \\
\hline W & 0.000 & 0.019 & 0.009 & 0.037 & 0.015 & 0.063 & 0.016 \\
\hline $\mathrm{Nb}$ & 1.236 & 1.407 & 0.986 & 1.046 & 1.588 & 1.306 & 1.556 \\
\hline $\mathrm{Ta}$ & 0.624 & 0.397 & 0.910 & 0.788 & 0.338 & 0.539 & 0.357 \\
\hline $\mathrm{Ti}$ & 0.168 & 0.217 & 0.109 & 0.102 & 0.076 & 0.103 & 0.039 \\
\hline $\mathrm{Zr}$ & 0.001 & 0.000 & 0.011 & 0.003 & 0.000 & 0.000 & 0.000 \\
\hline $\mathrm{Sn}$ & 0.062 & 0.039 & 0.032 & 0.021 & 0.012 & 0.014 & 0.060 \\
\hline $\mathrm{Al}$ & 0.005 & 0.000 & 0.001 & 0.020 & 0.003 & 0.001 & 0.001 \\
\hline V & 0.0001 & 0.002 & 0.001 & 0.000 & 0.000 & 0.000 & 0.000 \\
\hline B site & 2.096 & 2.082 & 2.058 & 2.017 & 2.033 & 2.026 & 2.029 \\
\hline $\mathrm{Ca}$ & 0.002 & 0.001 & 0.003 & 0.006 & 0.001 & 0.002 & 0.005 \\
\hline $\mathrm{Mn}$ & 0.063 & 0.331 & 0.425 & 0.416 & 0.424 & 0.614 & 0.748 \\
\hline $\mathrm{Fe}$ & 0.822 & 0.580 & 0.511 & 0.622 & 0.535 & 0.348 & 0.218 \\
\hline A site & 0.885 & 0.912 & 0.938 & 1.044 & 0.960 & 0.964 & 0.972 \\
\hline $\mathrm{Mn} /(\mathrm{Mn}+\mathrm{Fe})$ & 0.071 & 0.363 & 0.454 & 0.401 & 0.442 & 0.638 & 0.774 \\
\hline $\mathrm{Ta} /(\mathrm{Ta}+\mathrm{Nb})$ & 0.335 & 0.220 & 0.480 & 0.430 & 0.175 & 0.292 & 0.186 \\
\hline
\end{tabular}

$\mathrm{N}^{\circ}$ of ions (in apfu) calculated on the basis of $6 \mathrm{O}$. Clf: columbite-(Fe), Clm: columbite-(Mn), b.d.1.: below detection limit, - not analyzed.
Two different generations of columbite-(Fe) crystallized in the inner intermediate zone of the granite-like pegmatite dikes: columbite-(Fe) I and columbite-(Fe) II. The first, columbite- $(\mathrm{Fe}) \mathrm{I}$, occurs as millimetre-sized anhedral to subhedral crystals included in cassiterite. They usually exhibit a distinct zoning (Fig. 4b) owing to variations in the $\mathrm{Fe}$ and $\mathrm{Mn}$ versus $\mathrm{Nb}$ and Ta contents, the latter being almost invariable. As a consequence, a horizontal trend is seen in the columbite quadrilateral (Fig. 5). Chemically, columbite-(Fe) I is strongly enriched in $\mathrm{Nb}(1.236-1.493$ $a p f u)$ and less in Ta (0.381-0.624 apfu), with high Ti contents (up to 0.226 apfu) and trace amounts of $\mathrm{Sn}, \mathrm{Zr}$ and $\mathrm{W}$ occupying the $B$ site in the general formula $\mathrm{AB}_{2} \mathrm{O}_{6}$ (Von Knorring and Fadipe 1981). Iron (between 0.580 and $0.828 \mathrm{apfu}$ ) and $\mathrm{Mn}$ (up to 0.331 apfu) fill the A site almost completely (Tab. 2). Consequently, the $\mathrm{Mn} /(\mathrm{Mn}$ $+\mathrm{Fe})$ ratio ranges widely from 0.073 to 0.363 , owing to the zoned textures, whereas the variation in the $\mathrm{Ta} /(\mathrm{Ta}+\mathrm{Nb})$ ratio is more limited (0.203-0.335).

Columbite-( $\mathrm{Fe}$ ) II occurs as millimetre-sized prismatic crystals together with cassiterite and quartz (Fig. 4c). Its chemical composition features mutually comparable $\mathrm{Nb}$ and Ta contents occupying the $B$ site (up to 1.046 and 0.940 apfu respectively), with very low or, in some cases, significant amounts of Sn, W and Ti (up to 0.032, 0.037 and 0.109 apfu respectively). The $A$ site is mainly filled by $\mathrm{Fe}$ (up to 0.622 apfu) and Mn (up to 0.427 apfu) in similar proportions (Tab. 2). The sum of the $A$ - and $B$-site occupancies in the majority of the columbite-(Fe) II crystals is close, or equal, to $3 \mathrm{apfu}$, some of them reaching as much as 3.062. This would suggest the presence of trivalent cations in the structure (Ercit 1994), similar to the columbite-group minerals in the Lacorne and Lamotte pegmatites, Canada (Mulja et al. 1996). However, this cannot be the case here as all the $\mathrm{Fe}$ is $\mathrm{Fe}^{2+}$, as calculated by charge balance according to Ercit et al. (1992). The columbite-(Fe) II of the granite-like pegmatite dikes has intermediate $\mathrm{Mn} /(\mathrm{Mn}+\mathrm{Fe})$ and $\mathrm{Ta} /(\mathrm{Ta}+\mathrm{Nb})$ ratios, which are similar to each other and vary between 0.401 and 0.456 and between 0.430 and 


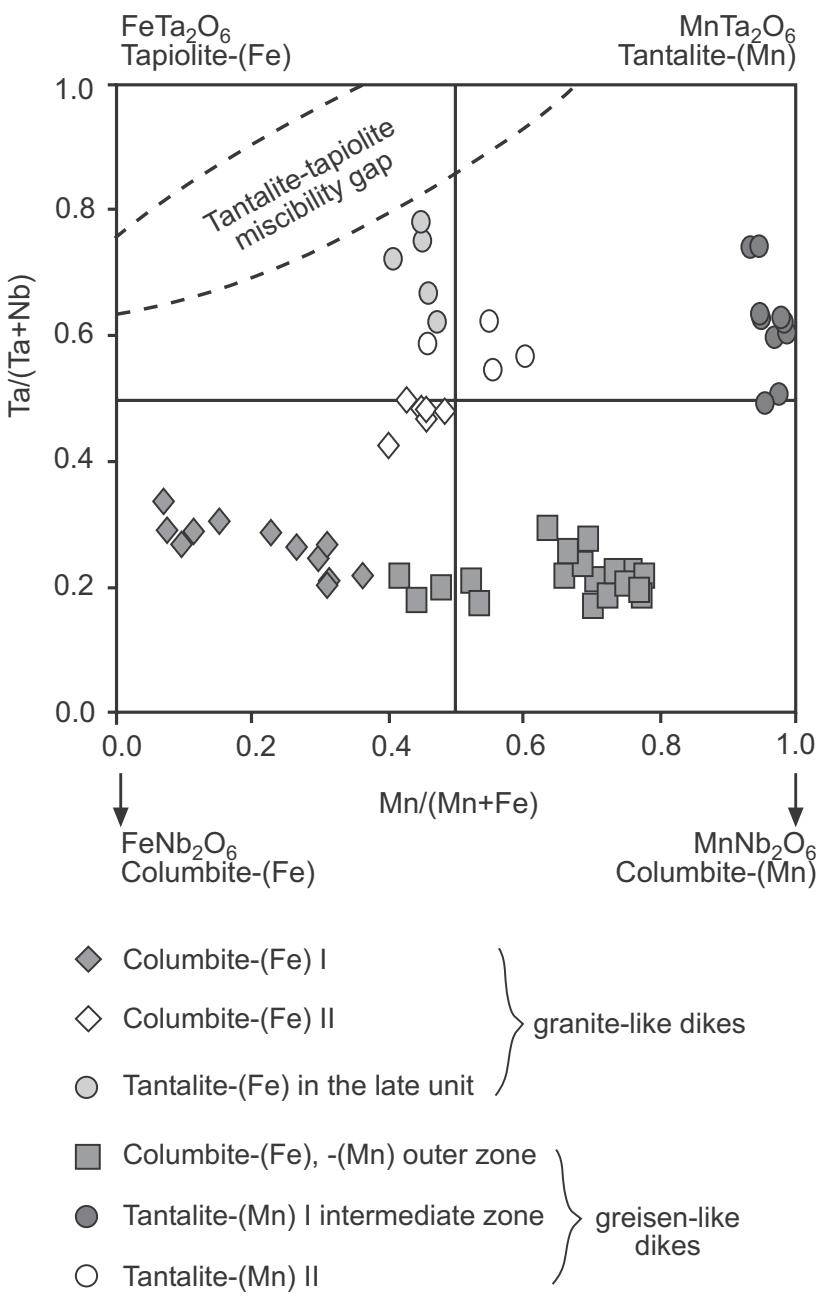

Fig. 5 Compositions of the $\mathrm{Nb}-\mathrm{Ta}$ oxides from the Cruz del Rayo peribatholithic pegmatite dikes and the late albite unit in the columbite-tantalite quadrilateral.

0.494 respectively, thus plotting in intermediate zones of the columbite classification diagram (Fig. 5).

The late albite unit only contains tantalite- $(\mathrm{Fe})$, which appears as micrometric, subhedral to anhedral crystals. They commonly show a slight zoning in which the Ta contents increase progressively rimwards (Fig. 4d). According to the chemical composition, Ta dominates over $\mathrm{Nb}$ at the $B$ site, reaching $1.602 a p f u$ and 0.753 apfu respectively, with only trace amounts of Ti and Sn (Tab. $3)$. Iron and manganese fill the $A$ site in similar quantities, although the Fe contents (up to 0.497 apfu) are always higher than those of Mn (up to $0.423 \mathrm{apfu}$ ). Consequently, the $\mathrm{Mn} /(\mathrm{Mn}+\mathrm{Fe})$ ratio ranges from 0.408 to 0.473 , whereas the $\mathrm{Ta} /(\mathrm{Ta}+\mathrm{Nb})$ ratio varies from 0.624 to 0.782 apfu (Fig. 5).

As mentioned above, both the primary and the secondary $\mathrm{Nb}$ and $\mathrm{Ta}$ assemblages in the greisen-like pegmatite dikes crystallized from the wall zone to the intermediate zone (Fig. 2c), usually being associated with cassiterite.
The primary assemblage consists of columbite-(Fe), columbite-(Mn) and tantalite-(Mn) I, whereas the secondary one is composed of tantalite-(Mn) II and - locally - tantalite-(Fe).

Columbite- $(\mathrm{Fe})$ developed in the wall zone of the pegmatite dikes as micrometre-sized anhedral exsolution blebs clustered in certain zones of the cassiterite crystals. Its composition is strongly enriched in $\mathrm{Nb}$ (1.247-1.591 apfu) over Ta (0.272-0.637 apfu) and the mineral contains significant Ti (up to $0.154 a p f u$ ), Sn (up to $0.103 \mathrm{apfu}$ ) and $\mathrm{W}$ (up to $0.029 \mathrm{apfu}$ ) in its $B$ site (Tab. $2)$. The $A$ site is occupied by variable $\mathrm{Fe}(0.508-0.683$ apfu) and minor Mn contents (0.278-0.464 apfu). As a consequence, the $\mathrm{Mn} /(\mathrm{Mn}+\mathrm{Fe})$ ratio ranges from 0.418 to 0.478 , whereas the $\mathrm{Ta} /(\mathrm{Ta}+\mathrm{Nb})$ ratio shows a more restricted variation (0.176-0.217; Fig. 5).

Columbite-(Mn) is relatively abundant in the greisenlike pegmatite dikes. It generally occurs as micrometresized subhedral to euhedral inclusions near the rims of cassiterite crystals and, in some cases, as prismatic crystals associated with quartz and muscovite. The columbite-(Mn) exhibits a strong oscillatory zoning owing to variations in the contents of the $\mathrm{Fe}-\mathrm{Mn}$ and $\mathrm{Nb}-\mathrm{Ta}$ pairs (Fig. 5) (Anderson et al. 1998). Some of the grains show a reverse zoning, featuring higher $\mathrm{Nb}$ contents in the rims than in the cores (Fig. 4e). This contrasts with the more common normal zoning pattern from the $\mathrm{Nb}$-rich cores to the Ta-rich rims described above. Such a reverse trend is usually explained as the result of a late hydrothermal replacement of the primary oxide minerals, which showed a normal zoning (Černý et al. 1992; Tindle and Breaks 1998, 2000). However, in this case the absence of typical replacement textures (e.g. patchy zoning) and the planar limits displayed by the growth zones, which should be parallel to gradual changes in composition, would suggest a primary origin for these crystals (Beurlen et al. 2008; Rao et al. 2009; Chudík et al. 2011). Moreover, the crystallization of cassiterite, which formed late in the crystallization sequence, coating the columbite-(Mn) (Fig. 4e), further supports the primary origin of these crystals. Thus, the causes for this reverse pattern could be established from the origin of the oscillatory zoning. The growth dynamics of the crystals, different concentrations of the main elements, fluctuating equilibrium and different solubilities of the two end-members are some of the processes described to explain the oscillatory zoning (Černý et al. 1985; Lahti 1987; Putnis et al. 1992; Johan and Johan 1994). They contain higher amounts of $\mathrm{Nb}$ (1.273-1.624 apfu) than Ta $(0.325-0.638 a p f u)$ in the $B$ site, which is completed by trace amounts of $\mathrm{Ti}, \mathrm{Zr}$ and W (Tab. 2). The $A$ site is occupied by Mn (0.503-0.748 $a p f u)$ and $\mathrm{Fe}(0.213-0.514 a p f u)$. The $\mathrm{Mn} /(\mathrm{Mn}+\mathrm{Fe})$ ratio ranges from 0.524 to 0.776 , whereas the $\mathrm{Ta} /(\mathrm{Ta}+\mathrm{Nb})$ ratio varies between 0.164 and 0.292 . 

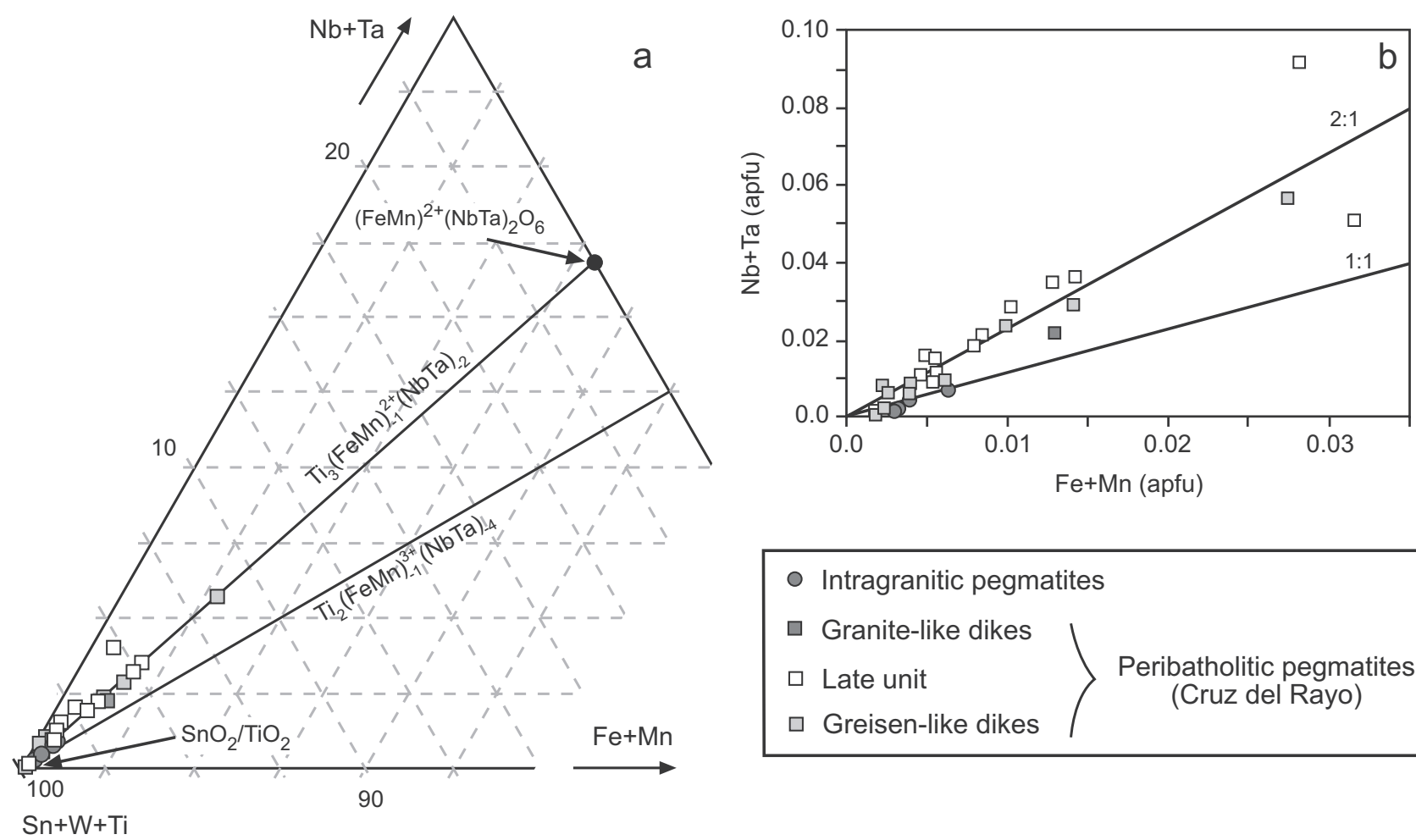

Fig. 6a- $-(\mathrm{Sn}+\mathrm{W}+\mathrm{Ti})-(\mathrm{Nb}+\mathrm{Ta})-(\mathrm{Fe}+\mathrm{Mn})$ triangular diagram representing the occupation of the cationic site and dominant substitution scheme in the studied cassiterite. $\mathbf{b}-\mathrm{Nb}+\mathrm{Ta} v s$. Fe $+\mathrm{Mn}$ diagram for the cassiterite from the pegmatite dikes.

Tantalite-(Mn) I crystallized in the intermediate zone of the greisen-like pegmatite dikes as micrometre-sized crystals commonly associated with white mica aggregates. These crystals also exhibit a compositional zoning, whereby the rims are progressively enriched in $\mathrm{Nb}$ (Fig. 4f). The tantalite-(Mn) I contains high Ta $(0.997-1.275$ $a p f u)$ and $\mathrm{Nb}$ contents $(0.510-1.014$ apfu) filling the $B$ site, which is completed with trace amounts of Ti and $\mathrm{Sn}$ (Tab. 3). Manganese clearly dominates over iron in the $A$ site, with up to 0.933 apfu. Thus, the $\mathrm{Mn} /(\mathrm{Mn}+\mathrm{Fe})$ ratio ranges from 0.931 to 0.986 , whereas the $\mathrm{Ta} /(\mathrm{Ta}+$ $\mathrm{Nb}$ ) ratio varies from 0.496 to 0.746 . All the analyses plot close to the vertical axis, i.e. at $\mathrm{Mn} /(\mathrm{Mn}+\mathrm{Fe})=1$, in the columbite classification diagram (Fig. 5).

Tantalite-(Mn) II has been identified less commonly both in the wall and intermediate zones of the greisenlike pegmatite dikes. It occurs as micrometre-sized crystals hosted by colourless border zones of cassiterite as well as thin rims surrounding previous columbite. Its composition is enriched in Ta (1.067-1.213 apfu) but less so in Mn (0.724-0.901 apfu), with up to 0.070 apfu $\mathrm{Ti}$ and 0.025 apfu $\mathrm{Sn}$. The $A$ site is occupied by similar quantities of $\mathrm{Fe}$ and $\mathrm{Mn}$ (up to 0.433 and 0.565 respectively), the latter always dominating slightly over the former. Thus, the $\mathrm{Mn} /(\mathrm{Mn}+\mathrm{Fe})$ ratio ranges from 0.549 to 0.603 , whereas the $\mathrm{Ta} /(\mathrm{Ta}+\mathrm{Nb})$ ratio is fairly homogeneous, varying between 0.542 and 0.626 . Tantalite-(Mn)
II plots in central part of the columbite classification diagram (Fig. 5).

Finally, only a single tantalite- $(\mathrm{Fe})$ crystal was identified in a greisen-like pegmatite. It shows a composition similar to the tantalite-(Mn) II described above (Tab. 3), with $\mathrm{Mn} /(\mathrm{Mn}+\mathrm{Fe})$ and $\mathrm{Ta} /(\mathrm{Ta}+\mathrm{Nb})$ ratios of 0.457 and 0.584 respectively (Fig. 5).

\section{Discussion}

\subsection{Substitution mechanisms in $\mathrm{Sn}-\mathrm{Nb}-\mathrm{Ta}-\mathrm{Ti}$ oxides}

The composition of the cassiterite analysed in the individual granitic and pegmatite rock types of the Jálama granitic cupola displays variations mainly in $\mathrm{Nb}$ and $\mathrm{Ta}$, instead of $\mathrm{Fe}$ and $\mathrm{Mn}$ contents. According to the data plotted in Fig. $6 \mathrm{a}-\mathrm{b}, \mathrm{Nb}$ and Ta clearly entered the structure of cassiterite from the granites, aplites and pegmatites of the Jálama Batholith by means of a columbitetype substitution $\left[\mathrm{Ti}_{3}(\mathrm{Fe}, \mathrm{Mn})_{-1}(\mathrm{Ta}, \mathrm{Nb})_{-2}\right]$. In both figures, analyses of cassiterite from the pegmatite dikes fall close to the line of the ideal $(\mathrm{Ta}+\mathrm{Nb}) /(\mathrm{Fe}+\mathrm{Mn})=2$. This is typical of many rare-element granitic pegmatites worldwide, as demonstrated by Tindle and Breaks (1998). This ratio is less than 2 for the cassiterite from the intragranitic 
pegmatite dikes, indicating that their $\mathrm{Ta}$ and $\mathrm{Nb}$ contents were probably not exclusively controlled by included particles and exsolved blebs of columbite-group minerals (Möller et al. 1988). Moreover, in the $(\mathrm{Sn}+\mathrm{W}+\mathrm{Ti})-(\mathrm{Nb}$ $+\mathrm{Ta})-(\mathrm{Fe}+\mathrm{Mn})$ triangular diagram plot these analyses close to the $(\mathrm{Sn}+\mathrm{W}+\mathrm{Ti})$ corner, suggesting an influence of minor $\mathrm{Sn}, \mathrm{W}$ and $\mathrm{Ti}$ in additional substitutions (Fig 6a).

The $\mathrm{TiO}_{2}$ contents are clearly higher in cassiterite from the intragranitic pegmatite dikes than in the Cruz del Rayo peribatholithic pegmatites. This implies that the residual melts responsible for the crystallization of the cassiterite in the intragranitic pegmatites could have been less evolved than those precipitating cassiterite in the peribatholithic dikes. In contrast, the $\mathrm{TiO}_{2}$ contents are very similar in the cassiterite from both the late albite unit and in the greisen-like dikes.

The main mechanisms of substitution in the $A$ and $B$ sites of the columbite-group minerals in the Jálama Batholith are represented in Fig. 7a-b. Two clearly distinct populations are seen: (i) primary columbite-group minerals from the granite-like pegmatite dikes, which are enriched mainly in $\mathrm{Nb}$ and $\mathrm{Fe}$, to the greisen-like pegmatite dikes, which are strongly enriched in Mn, and (ii) the crystals of the late albite unit and those resulting from exsolution processes, which show intermediate compositions or are Fe-enriched. Additionally, the reverse trend represented by the crystallization of the columbite-(Mn) in the greisen-like pegmatite dikes, which is slightly more enriched in $\mathrm{Nb}$ than the columbite-(Fe) of the granite-like pegmatites, can be observed in Fig. 7a.

The columbite-group minerals of the granite-like pegmatite dikes host significantly more $\mathrm{Ti}$ (up to 4.75 wt. $\% \mathrm{TiO}_{2}$ ) than those of the greisen-like dikes (up to 3.26 wt. $\% \mathrm{TiO}_{2}$ ), the latter containing almost no $\mathrm{Ti}$ in the innermost zones. These differences between both pegmatite types are represented in Fig. 7c. Thus, considering the correlations represented in Fig. 6a-b, and according to the data for the columbite-group minerals plotted in Fig. 8, the incorporation of $\mathrm{Fe}, \mathrm{Mn}, \mathrm{Nb}, \mathrm{Ta}$ and $\mathrm{Ti}$ into the crystal lattice would have been possible owing to the $3 \mathrm{Ti}^{4+} \leftrightarrow 2(\mathrm{Nb}, \mathrm{Ta})^{5+}+(\mathrm{Fe}, \mathrm{Mn})^{2+}$ coupled substitution. The fact that the sum of the cations filling the $B$ site, $\mathrm{Nb}$ $+\mathrm{Ta}+\mathrm{Ti}$, is slightly higher than 2 , seems to confirm the significant role of this substitution mechanism in most of these minerals (Ercit 1994).
Tab. 3 Representative compositions of tantalite in the Cruz del Rayo peribatholithic pegmatites (wt. \% and $a p f u$ )

\begin{tabular}{|c|c|c|c|c|c|c|}
\hline \multirow{2}{*}{$\begin{array}{l}\text { Peg. type } \\
\text { Mineral }\end{array}$} & \multicolumn{4}{|c|}{ Greisen } & \multicolumn{2}{|c|}{ Late Unit } \\
\hline & Tnf & Tnm I & Tnm I & Tnm II & $\operatorname{Tnf}$ & Tnf \\
\hline Analyses & 7.2 & 1.2 & 1.3 & 7.3 & 2.1 & 2.3 \\
\hline $\mathrm{WO}_{3}$ & 0.13 & - & - & 0.00 & - & - \\
\hline $\mathrm{Nb}_{2} \mathrm{O}_{5}$ & 23.29 & 22.05 & 30.50 & 25.91 & 13.75 & 19.33 \\
\hline $\mathrm{Ta}_{2} \mathrm{O}_{5}$ & 54.42 & 62.12 & 52.75 & 56.80 & 70.53 & 65.33 \\
\hline $\mathrm{TiO}_{2}$ & 0.93 & 0.10 & 0.11 & 0.92 & 1.36 & 0.37 \\
\hline $\mathrm{ZrO}_{2}$ & 2.25 & 0.00 & 0.00 & 0.46 & 0.00 & 0.00 \\
\hline $\mathrm{SnO}_{2}$ & 5.02 & b.d.1. & b.d.1. & 0.85 & 0.45 & 0.17 \\
\hline $\mathrm{UO}_{2}$ & - & 0.06 & 0.08 & - & 0.12 & b.d.1. \\
\hline $\mathrm{Al}_{2} \mathrm{O}_{3}$ & 0.05 & 0.03 & 0.29 & 0.02 & 0.38 & 0.03 \\
\hline $\mathrm{V}_{2} \mathrm{O}_{3}$ & b.d.1. & - & - & 0.00 & - & - \\
\hline $\mathrm{Bi}_{2} \mathrm{O}_{3}$ & - & 0.00 & 0.00 & - & 0.00 & b.d.1. \\
\hline $\mathrm{CaO}$ & 0.05 & 0.00 & 0.05 & 0.04 & b.d.1. & b.d.1. \\
\hline $\mathrm{MnO}$ & 6.48 & 14.52 & 14.85 & 9.27 & 5.98 & 6.59 \\
\hline $\mathrm{FeO}$ & 7.80 & 0.34 & 0.41 & 6.19 & 7.34 & 7.85 \\
\hline Total & 100.42 & 99.24 & 99.09 & 100.48 & 99.92 & 99.76 \\
\hline W & 0.002 & 0.000 & 0.000 & 0.000 & 0.000 & 0.000 \\
\hline $\mathrm{Nb}$ & 0.766 & 0.748 & 0.988 & 0.843 & 0.482 & 0.662 \\
\hline $\mathrm{Ta}$ & 1.076 & 1.268 & 1.028 & 1.112 & 1.486 & 1.346 \\
\hline $\mathrm{Ti}$ & 0.051 & 0.006 & 0.006 & 0.049 & 0.079 & 0.021 \\
\hline $\mathrm{Zr}$ & 0.080 & 0.000 & 0.000 & 0.016 & 0.000 & 0.000 \\
\hline $\mathrm{Sn}$ & 0.163 & 0.001 & 0.001 & 0.027 & 0.015 & 0.006 \\
\hline $\mathrm{Al}$ & 0.004 & 0.002 & 0.025 & 0.002 & 0.035 & 0.002 \\
\hline V & 0.000 & 0.000 & 0.000 & 0.000 & 0.000 & 0.000 \\
\hline B site & 2.143 & 2.025 & 2.048 & 2.050 & 2.098 & 2.038 \\
\hline $\mathrm{U}$ & 0.000 & 0.001 & 0.001 & 0.000 & 0.002 & 0.001 \\
\hline $\mathrm{Bi}$ & 0.000 & 0.000 & 0.000 & 0.000 & 0.000 & 0.000 \\
\hline $\mathrm{Ca}$ & 0.004 & 0.000 & 0.004 & 0.003 & 0.001 & 0.001 \\
\hline $\mathrm{Mn}$ & 0.399 & 0.923 & 0.902 & 0.565 & 0.392 & 0.423 \\
\hline $\mathrm{Fe}$ & 0.474 & 0.021 & 0.025 & 0.373 & 0.476 & 0.498 \\
\hline A site & 0.877 & 0.945 & 0.931 & 0.942 & 0.871 & 0.923 \\
\hline $\mathrm{Mn} /(\mathrm{Mn}+\mathrm{Fe})$ & 0.457 & 0.978 & 0.974 & 0.603 & 0.452 & 0.460 \\
\hline $\mathrm{Ta} /(\mathrm{Ta}+\mathrm{Nb})$ & 0.584 & 0.629 & 0.510 & 0.569 & 0.755 & 0.670 \\
\hline
\end{tabular}

$\mathrm{N}^{\circ}$ of ions (in apfu) calculated on the basis of $6 \mathrm{O}$. Tnf: tantalite-(Fe), Tnm: tantalite(Mn), b.d.l.: below detection limit, - not analyzed.

\subsection{Chemical evolution of the columbite- group minerals}

The chemical composition of the columbite-group minerals described in the Cruz del Rayo peribatholithic pegmatite dikes and the late albite unit is presented in Fig. 5. Two groups can be distinguished.

The first reveals, in general, a progressive enrichment in Mn, which is followed by an abrupt enrichment in Ta. On the one hand, the $\mathrm{Mn} /(\mathrm{Mn}+\mathrm{Fe})$ ratio of the 

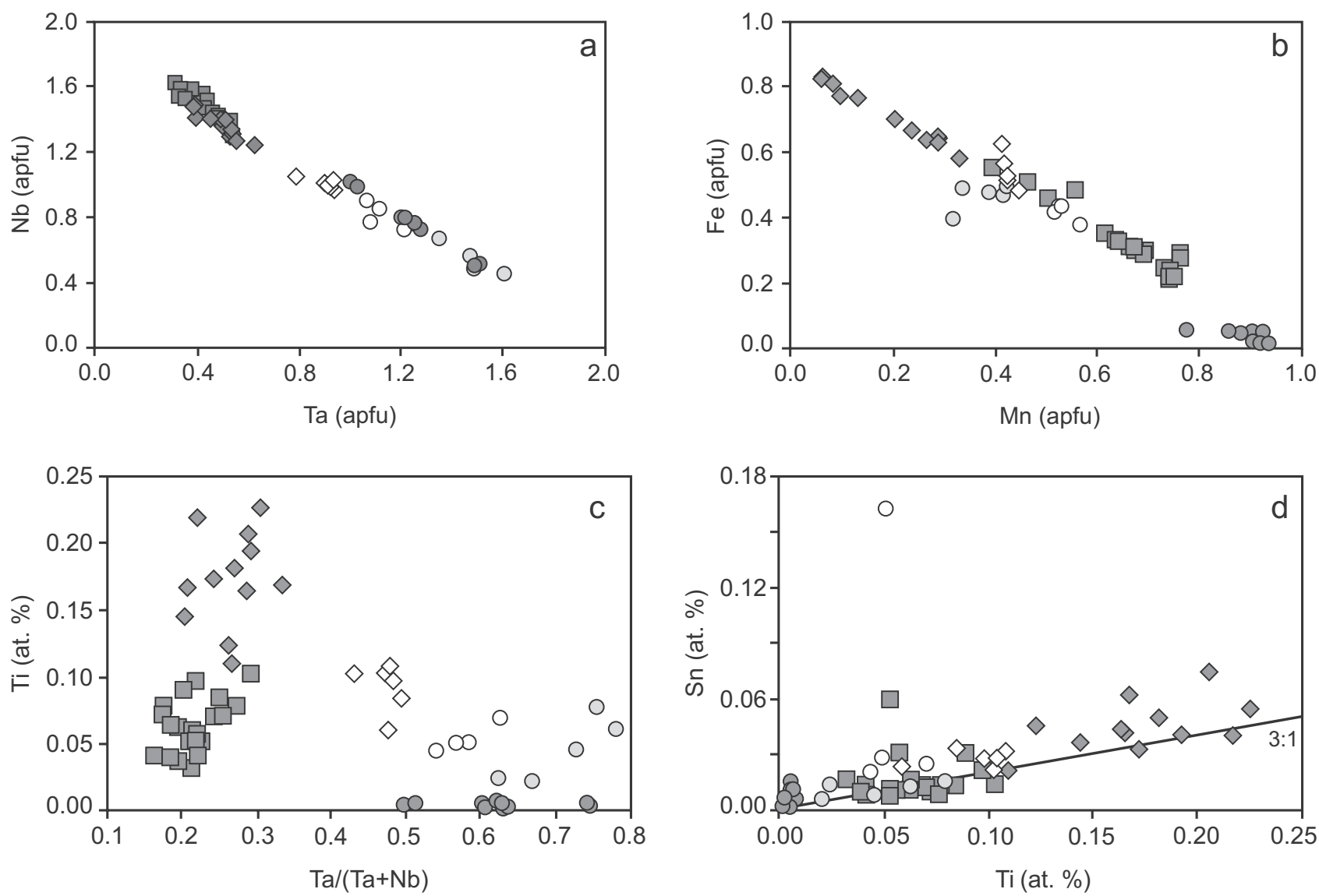

Fig. 7 Variation diagrams of the columbite-group minerals of the Cruz del Rayo peribatholithic pegmatite dikes: $\mathbf{a}-\mathrm{Nb} v s$. Ta; $\mathbf{b}-\mathrm{Fe} v s . \mathrm{Mn}$; $\mathbf{c}-\mathrm{Ti} v s . \mathrm{Ta} /(\mathrm{Ta}+\mathrm{Nb})$ and $\mathbf{d}-\mathrm{Sn} v s$. Ti. The legend is the same as in Fig. 5.

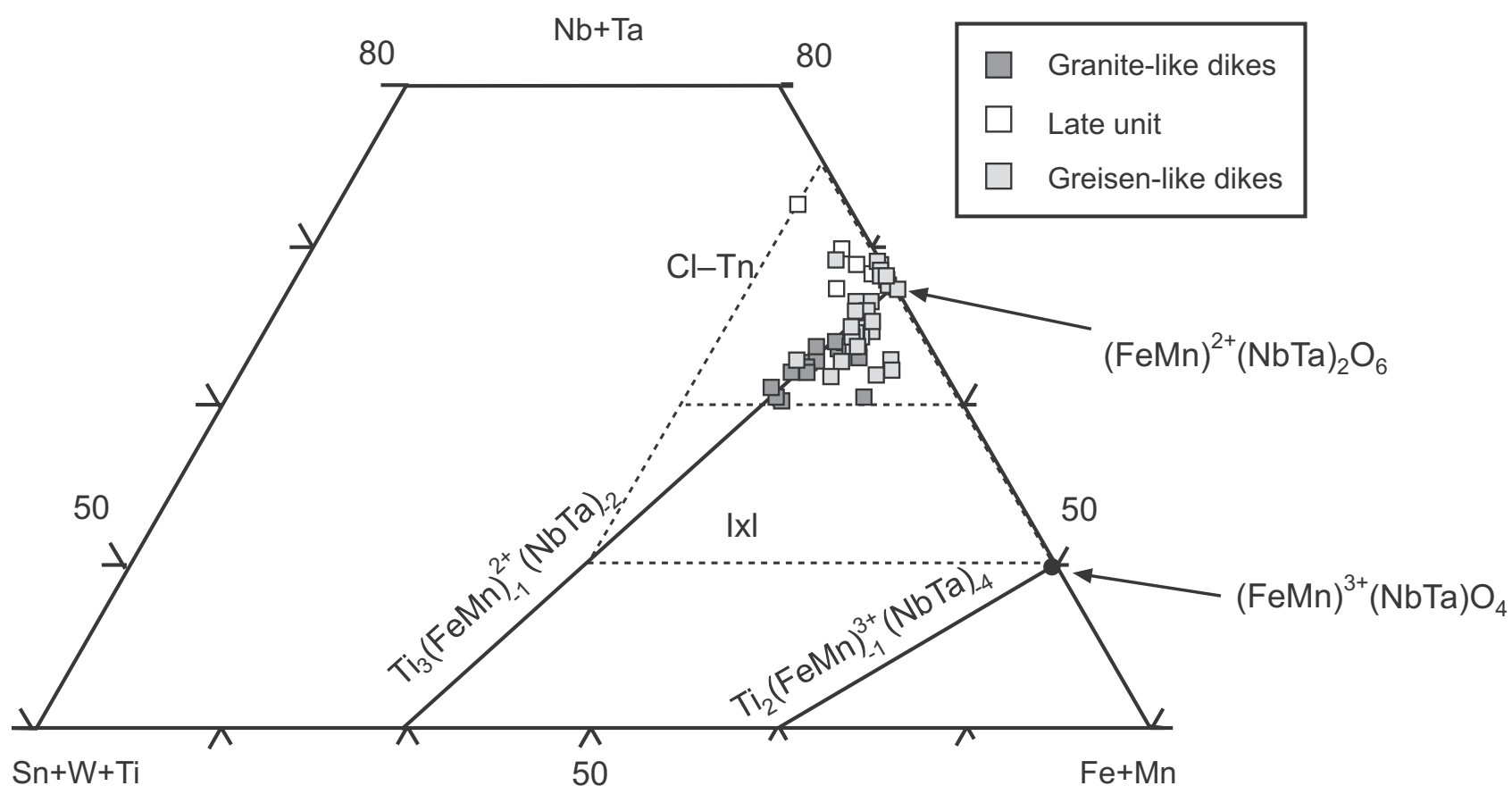

Fig. 8 Compositions of the columbite-group minerals $(\mathrm{Cl}-\mathrm{Tn})$ of the pegmatite dikes plotted in the $(\mathrm{Sn}+\mathrm{W}+\mathrm{Ti})-(\mathrm{Nb}+\mathrm{Ta})-(\mathrm{Fe}+\mathrm{Mn})$ triangular diagram. The dominant substitution mechanism can be observed. The ixiolite field (Ixl) is also outlined. 
columbite-group minerals in the granite-like pegmatite dikes evolves from 0.07 to 0.36 , whereas the $\mathrm{Ta} /(\mathrm{Ta}+$ $\mathrm{Nb}$ ) ratio remains low and more or less constant. This trend reflects the primary minerals crystallization in these pegmatite bodies. On the other hand, the tantalite$(\mathrm{Fe})$ hosted by the late albite unit shows the highest $\mathrm{Ta} /$ $(\mathrm{Ta}+\mathrm{Nb})$ ratio, following an upward trend. It represents the late crystallization of the columbite-group minerals owing to replacement processes during a Na-metasomatism. This alteration would have caused albitization of the pegmatite dikes (both intragranitic and, especially, the peribatholithic ones) and crystallization of the late albite unit.

The second group represents the columbite-group minerals of the greisen-like pegmatite dikes, which show a wide variation in the $\mathrm{Mn} /(\mathrm{Mn}+\mathrm{Fe})$ and the $\mathrm{Ta} /(\mathrm{Ta}+$ $\mathrm{Nb}$ ) ratios, depending on the hosting zone. These values range from 0.418 to 0.776 and from 0.176 to 0.292 , respectively, in the outermost zones of the dikes, following a horizontal branch in the diagram of Fig. 5. In contrast, they vary between 0.931 and nearly 1.000 and between 0.496 and 0.746 , respectively, in the innermost zones of the greisen-like dikes, forming a vertical branch in Fig. 5 . This evolutionary trend, again representing a Mn-enrichment followed by a strong Ta-enrichment, could have responded to the crystallization of the primary columbitegroup minerals in the greisen-like pegmatite dikes as a consequence of the fractionation of their parental melts. Moreover, it could also have been favoured by a high fluorine activity in the greisen-type dikes, which would have been responsible for a very high $\mathrm{Mn} / \mathrm{Fe}$ ratio (e.g. Černý and Ercit 1985; Černý et al. 1986; Černý 1989). Finally, the secondary assemblage of the columbite-group minerals exhibits a less pronounced enrichment in $\mathrm{Mn}$ than the primary one. Thus, they have a $\mathrm{Mn} /(\mathrm{Mn}+\mathrm{Fe})$ ratio varying between 0.401 and 0.603 and $\mathrm{a} \mathrm{Ta} /(\mathrm{Ta}+\mathrm{Nb})$ ratio ranging from 0.564 to 0.739 . In general, similar evolutionary trends are represented by the columbite-group minerals of other LCT pegmatites, such as the northern group of the Cross Lake pegmatite field (Černý and Ercit 1985) and Greer Lake (Černý et al. 1986), both in Manitoba; the beryl-columbite phosphate pegmatites of the Sebago granite-pegmatite system, Maine, USA (Wise and Brown 2010), Los Chilenitos, Argentina (Sosa et al. 2002), and Cap de Creus, Spain (Alfonso et al. 1995).

As mentioned above, the columbite-group minerals in the granite-like pegmatite dikes of Cruz del Rayo have high Ti contents compared with those hosted by the greisen-like bodies (Fig. 7c). In this diagram, an abrupt decrease in $\mathrm{Ti}$ can be observed from the $\mathrm{Nb}$-, Ta-oxides of the granite-like pegmatites to those of the outermost zones of the greisen-like ones, whereas the $\mathrm{Ta} /(\mathrm{Ta}+\mathrm{Nb})$ ratio remains low and almost constant. This evolutionary trend corresponds to the horizontal branch in the columbite diagram (Fig 5). Thereafter, the Ti contents continue to decrease, but more slowly, in the inner zones of these dikes at higher values of the $\mathrm{Ta} /(\mathrm{Ta}+\mathrm{Nb})$ ratio. This trend is represented by the vertical branch in the columbite diagram, which, together with the previous trend, represents the crystallization of the primary oxide minerals. A less abrupt decrease in the Ti contents can be observed in the secondary columbite-group minerals of both pegmatite types and the late unit as the $\mathrm{Ta} / \mathrm{Ta}+$ $\mathrm{Nb}$ ) ratio increases, reflecting the normal behaviour of $\mathrm{Ti}$ in silicate melts. Plotting the Ti versus the Sn contents in the columbite-group minerals of the Cruz del Rayo pegmatites (Fig. 7d), a 3:1 positive correlation is observed to dominate both in the granite-like and greisen-like dikes and in the late albite unit. Thus, these minerals apparently tend to incorporate preferentially more Ti than Sn, probably owing to the reduced availability of the latter element as a consequence of the cassiterite crystallization.

\subsection{Factors controlling melt fractionation and ore deposition}

The primary $\mathrm{Mn} /(\mathrm{Mn}+\mathrm{Fe})$ and $\mathrm{Ta} /(\mathrm{Ta}+\mathrm{Nb})$ ratios of columbite-group minerals in the rare-element granitic pegmatites of Cruz del Rayo generally increase with differentiation. This evolutionary trend developed during the pegmatite bodies crystallization allows the composition of the original melt and the fluids controlling the mineralization to be inferred (e.g. Černý 1982, 1991; Černý and Ercit 1985, 1989; Mulja et al. 1996; Tindle and Breaks 2000; Beurlen et al. 2008). According to Linnen and Keppler (1997), the rise in the $\mathrm{Ta} /(\mathrm{Ta}+\mathrm{Nb})$ ratio as pegmatite melts crystallize can be accounted for in terms of the lower solubility of $\mathrm{Nb}$-rich columbite-group minerals in peraluminous melts. However, the progressive increase in $\mathrm{Mn} /(\mathrm{Mn}+\mathrm{Fe})$ ratio is harder to explain. The reason is that the solubility of the Fe-rich members of columbitegroup minerals in pegmatite melts is higher than that of the Mn-rich members (Linnen 2004a, b). Therefore, their fractionation trend could be controlled by two factors: first, by other Fe-bearing minerals formed during pegmatite crystallization (London et al. 2001), and second, by the increasing fluorine activity with the fractionation of the melt (Černý 1989, 1991).

The general evolutionary trend of the $\mathrm{Nb}$ and $\mathrm{Ta}$ oxide minerals points to a progressive enrichment in $\mathrm{Mn}$ from the granite-like pegmatite dikes to the greisen-like dikes of Cruz del Rayo, followed by an increase in the Ta contents at the final stages (Fig. 9) (Llorens and Moro 2010b). Linnen and Keppler (1997) noted that accessory phases favour $\mathrm{Nb}$ over $\mathrm{Ta}$ at early stage of magmatic evolution. In our case, this behaviour was observed in the columbite-group minerals hosted by the granite-like pegmatite dikes, which 


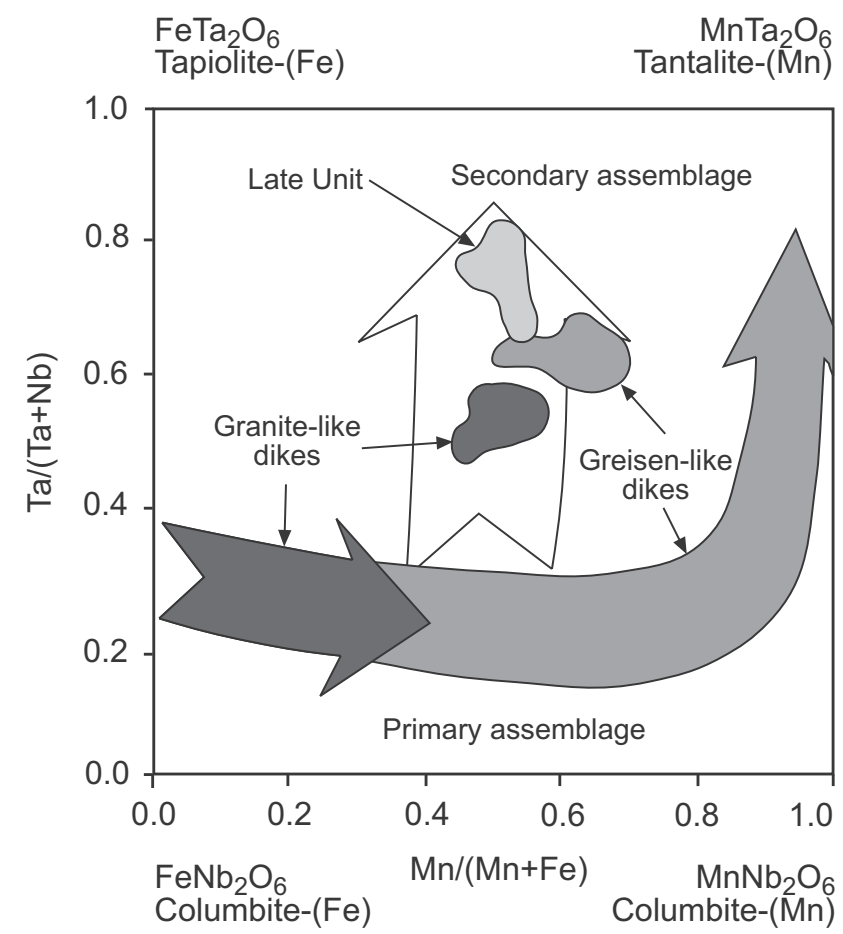

Fig. 9 Primary evolutional trend of the columbite-group minerals in the columbite quadrilateral, showing an enrichment in $\mathrm{Mn}$ and Ta from the Cruz del Rayo granite-like pegmatites (dark grey arrow) to the greisen-like bodies (light grey arrow), as well as a later Ta enrichment in the secondary assemblage (white arrow).

are especially enriched in $\mathrm{Nb}$ and $\mathrm{Fe}$. Therefore, the $\mathrm{Nb} / \mathrm{Ta}$ ratio would have decreased in the residual melt along fractionation, thereby crystallizing oxide minerals enriched in $\mathrm{Ta}$ and $\mathrm{Mn}$ in the greisen-like pegmatites.

According to the mineralogical composition of the granite-like pegmatite dikes they can be assumed to contain low amounts of F. Such a scenario could have been favoured by the lack of F-bearing minerals in these pegmatites and would therefore explain their relatively sparse mineralization. In addition, a limited $\mathrm{Fe}$ and $\mathrm{Fe}-$ Mn-rich phosphate assemblage crystallized in these pegmatites, such as the early alluaudite or the mitridatite and the late Mn-rich hydroxylapatite (Llorens and Moro 2012). This could have influenced Mn and Fe partitioning, thus shaping the oxide mineralization in the pegmatite dikes during both the primary and the secondary processes (e.g. Linnen and Cuney 2005).

The greisen-like pegmatite dikes are clearly deprived of Fe-bearing minerals and show an important crystallization of phosphates of the amblygonite-montebrasite series, only some of them containing more than $7 \mathrm{wt}$ \% F. This suggests a slight enhancement of the F contents with the fractionation of the residual melt from the crystallization of the granite-like pegmatites to the greisenlike dikes (Linnen 1998). Thus, the increasing fluorine activity would have been the main factor controlling mineral deposition in the greisen-like dikes. These higher $\mathrm{F}$ contents would have increased the solubility of the Ta-rich complexes, causing the Ta- and Mn-rich oxides to crystallize during the final consolidation stages of the pegmatite bodies, or even as a consequence of later replacement processes (Černý and Ercit 1985; Černý 1989, 1991; Linnen 1998).

As a result, the abundance of Fe-rich columbite-group minerals, showing broad variations in their Fe and $\mathrm{Mn}$ contents, together with the limited crystallization of Frich minerals in these pegmatite dikes, point to a low degree of evolution of their parental melts. The progressive melt differentiation causing crystallization of both the granite-like pegmatite and the greisen-like dikes would therefore have been responsible for the primary enrichment in Mn and, later, in Ta (Belkasmi et al. 2000; Linnen and Cuney 2005). Moreover, the higher amounts of $\mathrm{Fe}$ and the scarce Ti contents incorporated by the secondary columbite-group minerals could reflect partial dissolution and re-precipitation of the primary $\mathrm{Nb}-\mathrm{Ta}-$ oxide assemblages. However, certain influence of fluids exsolved from the surrounding metamorphic rocks, with or without meteoric fluids admixture, on the residual pegmatite melts could have played an important role in this Ti and Fe enrichment (Černý and Němec 1995; Tindle et al. 1998; Pal et al. 2007; Llorens and Moro 2010a). This external influx could have meant an entry of cations such as $\mathrm{Fe}$ and $\mathrm{Ti}$ into the system, which would have been incorporated to the secondary oxide minerals (Fig. 9). The crystallization of a broad variety of secondary phosphates enriched in $\mathrm{Fe}, \mathrm{Ca}, \mathrm{Mg}$ and $\mathrm{Sr}$ in both granitic facies of the Jálama Batholith, the related pegmatite dikes, and the CEG would support the idea of metamorphic \pm meteoric contamination (Llorens and Moro 2012).

The lack of suitable components in the pegmatite forming-melts would have limited the crystallization of cassiterite and columbite-group minerals in both the granitic facies of the EU and the pegmatite dikes hosted by them. Two causes can be envisaged.

Firstly, the mineral-forming components could have been fixed by the low amounts of ore minerals crystallized, e.g. cassiterite or rutile, which contain significant amounts of $\mathrm{Nb}$ and $\mathrm{Ta}$. Similar cases were $\mathrm{Sn}-\mathrm{Nb}-\mathrm{Ta}$ deposits of the granitic cupolas of Cínovec (Johan and Johan 1994), Podlesí (Breiter et al. 2007) and the Krásno-Horní Slavkov district (René and Škoda 2011), all in Erzgebirge (Bohemian Massif), as well as the rare-metal Yichun granite in China (Belkasmi et al. 2000).

Secondly, $\mathrm{Sn}, \mathrm{Nb}$ and $\mathrm{Ta}$ could have entered, as trace elements, the structure of the major rock-forming minerals that constitute the granitic and pegmatite rocks. Biotite and muscovite in particular scavenged these trace elements during their crystallization, containg up to $1020 \mathrm{ppm} \mathrm{Sn}$ in the granites and up to $981 \mathrm{ppm}$ in 
the intragranitic pegmatite dikes of the Jálama granitic cupola (Llorens 2011). Since concentration of $\mathrm{Sn}, \mathrm{Nb}$ and Ta was not sufficient for saturation of the essential oxide minerals, the trace elements would have been extracted from the melt to be incorporated in micas.

In contrast, columbite-group minerals crystallized in large quantities in the Cruz del Rayo pegmatite dikes, hosted by the metamorphic rocks and, especially, in those of greisen-like composition. The pegmatite bodies seem to have crystallized from the residual melts exsolved from the Jálama Batholith. Such liquids would have been extremely enriched in volatiles owing to fractionation processes, containing higher $\mathrm{Nb}$ and Ta contents than the intragranitic pegmatite-forming melts. The crystallization of abundant amblygonite-montebrasite series phosphates in these pegmatite bodies would have removed significant amounts of $\mathrm{F}$ and $\mathrm{Li}$ from the residual melt, thus reaching saturation in tantalite (Linnen 1998; Fiege et al. 2011). Accordingly, this process would have promoted the formation of the $\mathrm{Nb}$ and $\mathrm{Ta}$ oxides, whose composition would become progressively more Ta- and Mn-enriched as fractionation continued.

\subsection{Towards a comprehensive genetic model}

The $\mathrm{Sn}-\mathrm{Nb}-\mathrm{Ta}-\mathrm{Ti}$ oxides in the Jálama Batholith occur as accessory minerals disseminated throughout the border granitic facies of the EU (tourmaline-bearing leucogranite and aplites) and in the rare-element pegmatite dikes hosted by them (Černý and Ercit 2005). On the other hand, these oxides crystallized more abundantly in the Cruz del Rayo peribatholithic pegmatite dikes, hosted by the metamorphic rocks of the CEG. The EU of the Jálama Batholith is made up of a group of granites crystallized as a consequence of the fractional crystallization of a magma derived by partial melting of peraluminous and compositionally heterogeneous low-grade metamorphic rocks (Ramírez 1996; Ramírez and Grundvig 2000). The emplacement of the magma would have generated convective cells, concentrating the more volatile-rich residual melt, which would have been strongly enriched in $\mathrm{F}, \mathrm{Cl}, \mathrm{P}$ and $\mathrm{B}$, towards the apical zone of the magma chamber (Fig. 10a). The overpressure caused in the chamber due to the fractional crystallization would have led to expulsion of the residual melts ( \pm fluids) into zones of structural weakness, where a large number of pegmatite dikes would have crystallized in situ, hosted by the granitic cupola. Both the granitic rocks and the related pegmatite bodies contain only locally disseminated cassiterite and rutile, because the $\mathrm{Sn}, \mathrm{Nb}$ and Ta quantities in the melt would have been too low for abundant ore minerals to crystallize. In some cases, the residual melts that were more evolved and enriched in volatiles could have escaped into zones of weakness, reaching a fair distance from the granitic cupola. They would have crystallized
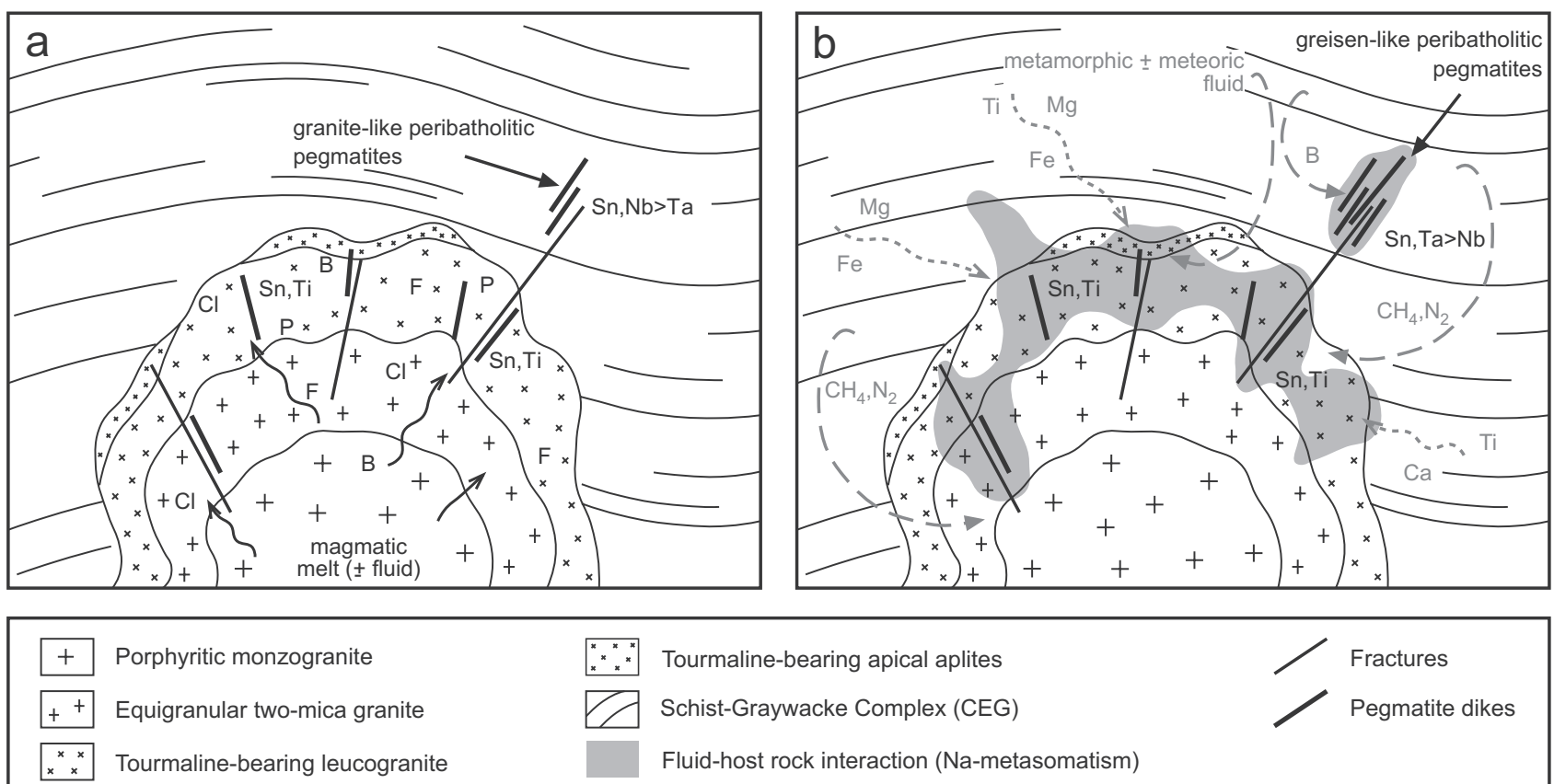

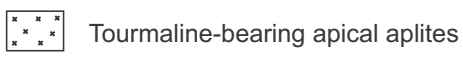

Schist-Graywacke Complex (CEG)

Fluid-host rock interaction (Na-metasomatism)

Fig. 10 Schematic evolutionary model for the Jálama granitic cupola. a - residual melts resulting from the Batholith's fractional crystallization, likely to be extremely enriched in volatiles, migrate through fractures to form the intragranitic and peribatholithic pegmatite dikes of granite-like composition, the latter containing scant mineralization of $\mathrm{Sn}$ and $\mathrm{Nb}>\mathrm{Ta}$ oxides; $\mathbf{b}$ - a generalized Na-metasomatism leads to crystallization of the late albite unit. Later, greisenization reactions could have formed the greisen-like pegmatite bodies, which host an important $\mathrm{Sn}$ and $\mathrm{Ta}>\mathrm{Nb}$ assemblage. The final influx of metamorphic and/or meteoric fluids favours crystallization of the secondary Nb-Ta assemblage. 
as a group of peribatholithic pegmatite dikes of granitelike composition, hosted by the metamorphic rocks of the CEG (Cruz del Rayo). These contain more abundant, disseminated cassiterite and columbite-group minerals enriched in $\mathrm{Nb}$ and Fe (Fig. 10a).

The residual melts from the pegmatite crystallization would have been extremely enriched in volatiles and hence in $\mathrm{Na}$, triggering the Na-metasomatism affecting the whole northern margin of the Jálama granitic cupola (Fig. 10b). As a consequence, the late albite unit would have crystallized in Cruz del Rayo. This process could have released large amounts of aqueous fluid that, together with the excess of volatiles, would have resulted in muscovitization and greisenization, thus producing the greisen-like pegmatite dikes. They contain an important deposit of cassiterite and columbite-group minerals, which are progressively enriched in Ta and Mn (Fig. 10b). Finally, the crystallization of a secondary assemblage of columbite-group minerals, with higher Fe contents, would correspond to hydrothermal alteration of the pegmatite bodies, which would have caused partial dissolution and re-precipitation of the oxide minerals and would have probably been influenced by the influx of external fluids coming from the metamorphic host rocks \pm meteoric fluids (Fig. 10b).

\section{Conclusions}

The Jálama Batholith represents a good example of a fractionated granitic cupola which has developed a series of Sn-, Nb-, Ta- and Ti-bearing intra- and peribatholithic pegmatites:

(i) The most fractionated facies of the Jálama Batholith, the tourmaline-bearing leucogranite and the apical aplites, host abundant rutile and ilmenite, whereas cassiterite is less abundant and tantalite-(Fe) occurs only locally.

(ii) The poorly zoned intragranitic pegmatites contain cassiterite as the main ore mineral, as well as scarce rutile and, locally, Ta-rich rutile.

(iii) The main $\mathrm{Sn}-\mathrm{Nb}-\mathrm{Ta}$ ore occurs in the Cruz del Rayo peribatholithic pegmatites, which contain abundant cassiterite and columbite-group minerals. Two evolutionary trends have been identified in these minerals. The first one represents a progressive enrichment in $\mathrm{Mn}$ and then in $\mathrm{Ta}$ of the primary $\mathrm{Nb}-\mathrm{Ta}$ assemblage from the granite-like dikes to the greisen-like bodies. The second trend reflects a Ta enrichment of the secondary $\mathrm{Nb}-\mathrm{Ta}$ assemblage in these dikes and in the late unit.

(iv) The factors controlling the fractionation trends of the primary columbite-group minerals likely were, on the one hand, the partitioning of $\mathrm{Fe}$ and $\mathrm{Mn}$ among individual minerals in the granite-like dikes and, on the other hand, the increasing fluorine activity of the residual pegmatite melts in the greisen-like bodies.

(v) Certain influence of metamorphic \pm meteoric fluids mixed with the residual pegmatite melts probably led to the crystallization of the secondary assemblage.

Acknowledgements. This study was supported by the Comunidad Autónoma de Castilla y León (Research Project Ref. SA015A06 and Research Fellowship). Thanks are due to Miguel Ángel Fernández, for performing many electron-microprobe analyses and providing BSE images as well as general assistance during the analytical work. We gratefully acknowledge M. Novák and V. Janoušek for their editorial handling and the comments on this paper, as well as P. Uher and M. Wise for their critical reviews and valuable improvements.

\section{References}

Alfonso P, Corbella M, Melgarejo J-C (1995) Nb-Taminerals from the Cap de Creus pegmatite field, eastern Pyrenees: distribution and geochemical trends. Mineral Petrol 55: 53-69

Anderson SD, Černý P, Halden NM, Chapman R, Uher P (1998) The YITT-B pegmatite swarm at Bernic Lake, southeastern Manitoba: a geochemical and paragenetic anomaly. Canad Mineral 36: 283-301

Belkasmi M, Cuney M, Pollard PJ, Bastoul A (2000) Chemistry of the $\mathrm{Ta}-\mathrm{Nb}-\mathrm{Sn}-\mathrm{W}$ oxide minerals from the Yichun rare metal granite (SE China): genetic implications and comparison with Moroccan and French Hercynian examples. Mineral Mag 64: 507-523

Beurlen H, Da Silva MrR, Thomas R, Soares DR, Olivier $\mathrm{P}$ (2008) $\mathrm{Nb}-\mathrm{Ta}-(\mathrm{Ti}-\mathrm{Sn})$ oxide mineral chemistry as tracer of rare-element granitic pegmatite fractionation in the Borborema Province, Northeastern Brazil. Miner Depos 43: 207-228

Bouchot V, Ledru P, Lerouge C, Lescuyer J-L, Milési J-P (2005) Late-Variscan mineralizing systems related to orogenic processes: the French Massif Central. Ore Geol Rev 27: 169-197

Breiter K, ŠKoda R, Uher P (2007) Nb-Ta-Ti-W-Sn-oXide minerals as indicators of peraluminous $\mathrm{P}$ - and F-rich granitic system evolution: Podlesí, Czech Republic. Mineral Petrol 91: 225-248

ČERNÝ P (1982) Anatomy and classification of granitic pegmatites. In: ČERNÝ P (ed) Granitic Pegmatites in Science and Industry. Mineralogical Association of Canada, Short-Course Handbooks 8: 1-32

ČERNÝ P (1989) Characteristics of pegmatite deposits of tantalum. In: Möller P, ČERNÝ P, SAUPÉ F (eds) Lanthanides, Tantalum and Niobium. SGA Special Publications 7: Springer-Verlag, New York, pp 195-239 
ČERNÝ P (1991) Fertile granites of Precambrian rare-element pegmatite fields: is geochemistry controlled by tectonic setting or source lithologies? Precambr Res 51:429-468

ČERNÝ P, ERCIT S (1985) Some recent advances in the mineralogy and geochemistry of $\mathrm{Nb}$ and $\mathrm{Ta}$ in rare-element granitic pegmatites. Bull Minéral 108: 499-532

ČERNÝ P, ERCIT S (1989) Mineralogy of niobium and tantalum: crystal chemical relationships, paragenetic aspects and their economic implications. In: MölLER P, ČERNÝ P, SAUPÉ F (eds) Lanthanides, Tantalum and Niobium. SGA Special Publications 7: Springer-Verlag, New York, pp 27-29

ČERNÝ P, ERCIT S (2005) The classification of granitic pegmatites revisited. Canad Mineral 43: 2005-2026

ČERNÝ P, NĚMEC D (1995) Pristine vs. contaminated trends in $\mathrm{Nb}$, Ta-oxide minerals of the Jihlava pegmatite district, Czech Republic. Mineral Petrol 55: 117-129

Černý P, Meintzer RE, Anderson AJ (1985) Extreme fractionation in rare-element granitic pegmatites: selected examples of data and mechanisms. Canad Mineral 23: 381-421

Černý P, Goad BE, Hawthorne C, Chapman R (1986) Fractionation trends of the $\mathrm{Nb}$ - and Ta-bearing oxide minerals in the Greer Lake pegmatitic granite and its pegmatite aureole, southeastern Manitoba. Amer Miner 71: 501-517

ČERnÝ P, Novák M, Chapman R (1992) Effects of sillimanite-grade metamorphism and shearing on $\mathrm{Nb}-\mathrm{Ta}$-oxide minerals in granitic pegmatites: Maršíkov, northern Moravia, Czechoslovakia. Canad Mineral 30: 699-718

Černý P, Blevin PL, Cuney M, London D (2005) Graniterelated ore deposits. Econ Geol 100 ${ }^{\text {th }}$ Anniversary Volume: $337-370$

Černý P, Novák M, Chapman R, Ferreira K (2007) Subsolidus behavior of niobian rutile from the Písek region, Czech Republic: a model for exsolution in $\mathrm{W}-$ and $\mathrm{Fe}^{2+}$ >> $\mathrm{Fe}^{3+}$-rich phases. J Geosci 52: 143-159

Charoy B (1986) The genesis of the Cornubian Batholith (southwest England): the example of the Carnmenellis Pluton. J Petrol 27: 571-604

Chudík P, Uher P, Gadas P, Š́oda R, PrŠek J (2011) Niobium-tantalum oxide minerals in the Jezuitské Lesy granitic pegmatite, Bratislava Massif, Slovakia: Ta to $\mathrm{Nb}$ and $\mathrm{Fe}$ to $\mathrm{Mn}$ evolutionary trends in a narrow Be, Cs-rich and Li, B-poor dike. Mineral Petrol 102: 15-27

Cuney M, Marignac C, Weisbrod A (1992) The Beauvoir topaz-lepidolite albite granite (Massif Central, France); the disseminated magmatic $\mathrm{Sn}-\mathrm{Li}-\mathrm{Ta}-\mathrm{Nb}-\mathrm{Be}$ mineralization. Econ Geol 87: 1766-1794

Cuney M, Alexandrov P, Le Carlier C, Cheilletz A, Raimbault L, Ruffet G, Scallet S (2002) The timing of Sn-W-rare metals mineral deposits of Western Variscan chain in their orogenic setting: the case of the Limousin area (French MassifCentral). In: Blundell DJ, Neubauer
F, vON QuADT A (eds) The Timing and Location of Major Ore Deposits in an Evolving Orogen. Geological Society of London Special Publications 204: 213-228

Díez Balda MA, García Casquero JL, Monteserín López V, Nozal Martín F, Pardo Alonso MV, Robles Casas R (1990) Sub-vertical shearing post-dating the second Hercynian phase of deformation south of Salamanca. Rev Soc Geol España 3: 117-125 (in Spanish)

ERCIT TS (1994) The geochemistry and crystal chemistry of columbite-group minerals from granitic pegmatites, southwestern Grenville Province, Canadian Shield. Canad Mineral 32: 421-438

Ercit TS, ČERnÝ P, Hawthorne FC, McCammon CA (1992) The wodginite group II. Crystal chemistry. Canad Mineral 30: 613-631

Fernández-Leyva C (2007) Metallogenetic Study of the Jálama Batholith and its Surroundings. Unpublished Ph.D. thesis, Univesidad Politéctnica de Madrid, pp 1-188 (in Spanish)

Fiege A, Kirchner C, Holtz F, Linnen RL, Dziony W (2011) Influence of fluorine on the solubility of manganotantalite $\left(\mathrm{MnTa}_{2} \mathrm{O}_{6}\right)$ and manganocolumbite $\left(\mathrm{MnNb}_{2} \mathrm{O}_{6}\right)$ in granitic melts - an experimental study. Lithos 122: 165-174

Fuertes-Fuentes M, Martin-Izard A (1998) The Forcarei Sur rare-element granitic pegmatite field and its associated mineralization, Galicia, Spain. Canad Mineral 36: 303-326

Hata K, Higuchi M, Takahashi J, Kodaira K (1996) Floating zone growth and characterization of aluminiumdoped rutile single crystals. J Cryst Growth 163: 279-284

JoHAN V, JohAN Z (1994) Accessory minerals of the Cínovec (Zinnwald) granite cupola, Czech Republic. Part 1: Nb-, Ta- and Ti-bearing oxides. Mineral Petrol 51: 323-343

LAнTI SI (1987) Zoning in columbite-tantalite crystals from the granitic pegmatites of the Eräjärvi area, southern Finland. Geochim Cosmochim Acta 51: 509-517

LinNEN RL (1998) The solubility of Nb-Ta-Zr-Hf-W in granitic melts with $\mathrm{Li}$ and $\mathrm{Li}+\mathrm{F}$ : constraints for mineralization in rare metal granites and pegmatites. Econ Geol 93: 1013-1025

LiNNEN RL (2004a) PIG comments and questions, reply. Accessed on March 30, 2012, at URL http://www.minsocam. org/msa/special/pig/PIG_CQ/PIG_CQ_Kjellman.html

LiNNEN RL (2004b) Ferrocolumbite-manganotantalite trends in granites and pegmatites: experimental and natural constraints. Geol Soc Amer Progr Abstr: 36

Linnen RL, Cuney M (2005) Granite-related rare-element deposits and experimental constraints on $\mathrm{Ta}-\mathrm{Nb}-\mathrm{W}-$ Sn-Zr-Hf mineralization. In: LinNEN RL, SAMSON IM (eds) Rare-element Geochemistry and Mineral Deposits. Geological Association of Canada Short Course Notes 17: 45-67

LinNen RL, Keppler H (1997) Columbite stability in granitic melts: consequences for the enrichment and fractionation 
of $\mathrm{Nb}$ and $\mathrm{Ta}$ in the Earth crust. Contrib Mineral Petrol 128: $213-227$

Llorens T (2011) The Sn-W-(Nb-Ta) magmatic-hydrothermal mineralizations of the Navasfrías district (SW Salamanca). Ph.D thesis, Salamanca University. Vítor Collection 290: pp 1-353. ISBN 978-84-7800-088-3 (in Spanish)

Llorens T, Moro, MC (2007) Preliminary study of intragranitic pegmatites in the $\mathrm{Sn}-\mathrm{W}-(\mathrm{Au})$ district of Navasfrías (SW of Salamanca, Spain). In: Martins T, Vieira R (eds) Granitic Pegmatites: the State of the Art, Book of Abstracts. Universidad do Porto, Department of Geology, Porto, Memórias 8: 56-57

Llorens T, Moro MC (2008) Al-Fe-Mn phosphates in the intragranitic pegmatites of the Navasfrías district (SW Salamanca). In: Delgado J, Astilleros JM, Bauluz B, Calvo B, González I, Herrero JM, López J, Proenza J, Rodríguez C (eds) XXVIII Reunión de la Sociedad Española de Mineralogía, XXI Reunión de la Sociedad Española de Arcillas. Sociedad Española de Mineralogía, Macla 9: 145-146 (in Spanish)

Llorens T, Moro MC (2010a) Microlite and tantalite in the LCT granitic pegmatites of La Canalita, Navasfrías Sn-W District, Salamanca, Spain. Can Mineral 48: 549-564

Llorens T, Moro MC (2010b) Columbite-group minerals in the Cruz del Rayo pegmatite dikes, SW Salamanca, Spain. In: PÁL-MolnÁr E ET AL (eds) IMA 2010, Bonds and Bridges, CD of Abstracts. Department of Mineralogy, Geochemistry and Petrology, University of Szeged, Budapest. Acta Mineralogica-Petrographica, Abstract Series 6: 167

Llorens T, Moro MC (2012) Fe-Mn phosphate associations as indicators of the magmatic-hydrothermal and supergene evolution of the Jálama Batholith in the Navasfrías Sn-W district, Salamanca, Spain. Mineral Mag 76: 1-24

London D, Morgan VI GB, Wolf MB (2001) Amblygonite-montebrasite solid solutions as monitors of fluorine in evolved granitic and pegmatitic melts. Amer Miner 86: 225-233

Martínez Catalán JR, Martínez Poyatos D, Bea F (2004) Centro-Iberic Zone. In: VERA JA (ed) Geology of Spain. SGE-IGME, Madrid, Spain, pp 68-133 (in Spanish)

Möller P, Dulski P, Szacki W, Malow G, Riedel E (1988) Substitution of tin in cassiterite by tantalum, niobium, tungsten, iron and manganese. Geochim Cosmochim Acta 52: 1497-1503

Mulja T, Williams-Jones AE, Martin RF, Wood SA (1996) Compositional variation and structural state of columbite-tantalite in rare-element granitic pegmatites of the Preissac-Lacorne Batholith, Quebec, Canada. Amer Miner 81: 146-157

Pal DC, Mishra B, Bernhardt H-J (2007) Mineralogy and geochemistry of pegmatite-hosted $\mathrm{Sn}-, \mathrm{Ta}-\mathrm{Nb}-$, and $\mathrm{Zr}-\mathrm{Hf}$-bearing minerals from the southeastern part of the Bastar-Malkangiri pegmatite belt, central India. Ore Geol Rev 30: 30-55

Putnis A, Fernández-Diaz L, Prieto M (1992) Experimentally produced oscillatory zoning in the $(\mathrm{Ba}, \mathrm{Sr}) \mathrm{SO}_{4}$ solid solution. Nature 358: 743-745

Raimbault L (1998) Composition of complex lepidolitetype granitic pegmatites and of constituent columbitetantalite, Chèdeville, Massif Central, France. Canad Mineral 36: 563-583

Raimbault L, Cuney M, Azencott C, Duthou JL, Joron JL (1995) Geochemical evidence for a multistage magmatic genesis of $\mathrm{Ta}-\mathrm{Sn}-\mathrm{Li}$ mineralization in the granite at Beauvoir, French Massif Central. Econ Geol 90: 548-576

RAmírez JA (1996) Petrological, Geochemical and Isotopic Study of the Jálama Batholith (Northern Extremadura) Unpublished PhD thesis, University of Granada, pp 1-201 (in Spanish)

Ramírez JA, Grundvig S (2000) Causes of geochemical diversity in peraluminous granitic plutons: the Jálama Pluton, Central-Iberian Zone (Spain and Portugal). Lithos 50: 171-190

Rao C, Wang RC, Hu H, Zhang WL (2009) Complex internal textures in oxide mineral from the Nanping No. 31 dyke of granitic pegmatite, Fujian Province, southeastern China. Canad Mineral 47: 1195-1212

ReNÉ M, ŠKODA R (2011) Nb-Ta-Ti oxides fractionation in rare-metal granites: Krásno-Horní Slavkov ore district, Czech Republic. Mineral Petrol 103: 37-48

RodA-Robles E (1993) Distribution, characteristics and petrogenesis of La Fregeneda pegmatites (Salamanca). Unpublished $\mathrm{PhD}$ thesis, University of the Basque Country, Bilbão, pp 1-199 (in Spanish)

Roda-Robles E, Vieira R, Lima A, Pesquera A, Noronha F, FONTAN F (2007) The Fregeneda-Almendra pegmatitic field (Spain and Portugal): mineral assemblages and regional zonation. In: MARTINS T, VIEIRA R (eds) Granitic Pegmatites: the State of the Art, Book of Abstracts. Universidad do Porto, Department of Geology, Porto, Memórias 8: 81-82

Rodríguez Alonso MD (1985) The Schist-Greywacke Complex and the Paleozoic rocks in the Spanish WestCentral part. Acta Salamant 51: 1-174 (in Spanish)

Ruiz C, Fernández-Leyva C, Locutura J (2008) Geochemistry, geochronology and mineralisation potential of the granites in the Central Iberian Zone: the Jálama Batholith. Chem Erde 68: 413-429

Sosa GM, Augsburger MS, Pedregosa JC (2002) Columbite-group minerals from rare-metal granitic pegmatites of the Sierra de San Luis, Argentina. Eur J Mineral 14: 627-636

Tindle AG, Breaks FW (1998) Oxide minerals of the Separation Rapids rare-element granitic pegmatite group, northwestern Ontario. Canad Mineral 36: 609-635 
Tindle AG, Breaks FW (2000) Columbite-tantalite mineral chemistry from rare-element granitic pegmatites: Separation Lake area, NW Ontario, Canada. Mineral Petrol 70: 165-198

Tindle AG, Breaks FW, WebB PC (1998) Wodginite-group minerals from the Separation Rapids rare-element granitic pegmatite group, northwestern Ontario. Canad Mineral 36: 637-658

Vieira R, Roda-Robles E, Pesquera A, Lima A (2011) Chemical variation and significance of micas from the Fregeneda-Almendra pegmatite field (Central-Iberian Zone, Spain and Portugal). Amer Miner 96: 637-645
Von KnORring O, Fadipe A (1981) On the mineralogy and geochemistry of niobium and tantalum in some granite pegmatites and alkali granites of Africa. Bull Minéral 104: 496-507

Willis-Richards J, Jackson NJ (1989) Evolution of the Cornubian ore field, southwest England: part 1. Batholith modeling and ore distribution. Econ Geol 84: 1078-1100

Wise A, BRown CD (2010) Mineral chemistry, petrology and geochemistry of the Sebago granite-pegmatite system, southern Maine, USA. J Geosci 55: 3-26 